\title{
Valorisation of algal biomass to value-added metabolites: emerging trends and opportunities
}

\author{
V. S. Uma - Zeba Usmani - Minaxi Sharma - Deepti Diwan - Monika Sharma • \\ Miao Guo - Maria G. Tuohy • Charalampos Makatsoris • Xiaobin Zhao • \\ Vijay Kumar Thakur • Vijai Kumar Gupta $\mathbb{D}$
}

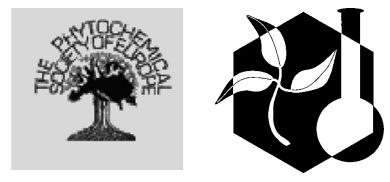

Received: 19 July 2021 / Accepted: 19 January 2022

(C) Crown 2022

\begin{abstract}
Algal biomass is a promising feedstock for sustainable production of a range of value-added compounds and products including food, feed, fuel. To further augment the commercial value of algal metabolites, efficient valorization methods and biorefining channels are essential. Algal extracts are ideal sources of biotechnologically viable compounds loaded with anti-microbial, anti-oxidative, anti-inflammatory, anti-cancerous and several therapeutic and restorative properties. Emerging technologies in
\end{abstract}

V. S. Uma, Zeba Usmani, Minaxi Sharma and Deepti Diwan have contributed equally to this work.

V. S. Uma

Radiological and Environmental Safety Group,

Department of Atomic Energy, Indira Gandhi Centre for Atomic Research (IGCAR), Govt of India, Kalpakkam, Tamil Nadu, India

\section{Z. Usmani · M. Sharma}

Department of Applied Biology, University of Science and Technology, Meghalaya 793101, India

D. Diwan

School of Medicine, Washington University, Saint Louis, MO, USA

M. Sharma

Department of Botany, Sri Avadh Raj Singh Smarak

Degree College, Gonda, UP, India biomass valorisation tend to reduce the significant cost burden in large scale operations precisely associated with the pre-treatment, downstream processing and waste management processes. In order to enhance the economic feasibility of algal products in the global market, comprehensive extraction of multi-algal product biorefinery is envisaged as an assuring strategy. Algal biorefinery has inspired the technologists with novel prospectives especially in waste recovery, carbon concentration/sequestration and complete utilisation of the value-added products in a sustainable closed-loop methodology. This review critically examines the latest trends in the algal biomass

\footnotetext{
M. Guo · C. Makatsoris

Department of Engineering, Faculty of Natural and Mathematical Sciences, King's College, Strand Campus, The Strand London, London WC2R 2LS, UK
}

M. G. Tuohy

Molecular Glycobiotechnology Group, Biochemistry,

School of Natural Sciences, Ryan Institute and MaREI, National University of Ireland, H91 TK33 Galway, Ireland

X. Zhao

Future Business Cambridge, Cambond Limited, Centre Kings Hedges Road, Cambridge CB4 2HY, UK

V. K. Thakur · V. K. Gupta ( $\bowtie)$

Biorefining and Advanced Materials Research Center, Scotland's Rural College (SRUC), Kings Buildings, West Mains Road, EH9 3JG Edinburgh, UK

e-mail:Vijai.Gupta@sruc.ac.uk 
valorisation and the expansive feedstock potentials in a biorefinery perspective. The recent scope dynamics of algal biomass utilisation such as bio-surfactants, oleochemicals, bio-stimulants and carbon mitigation have also been discussed. The existing challenges in algal biomass valorisation, current knowledge gaps and bottlenecks towards commercialisation of algal technologies are discussed. This review is a comprehensive presentation of the road map of algal biomass valorisation techniques towards biorefinery technology. The global market view of the algal products, future research directions and emerging opportunities are reviewed.

Keywords Algal biomass - Biorefinery $\cdot$ Algal biomass valorisation · Algal metabolites · Value added products $\cdot$ Circular bioeconomy

\section{Introduction}

Algae are versatile multicellular ubiquitous organisms known for their biotechnological and environmental significance. Algal forms are either micro or macroalgae and are known to be the oldest living microbes of the earth, which also explains its vast diversity (Stern et al. 2010). The existence of these mighty microbes dates back to 3.5 billion years (Margulis 1981). Algal species are known to subsist in coastal and aquatic habitats; however, they are also reported in extreme conditions such as hot springs, polar regimes, salt pans etc. (Show et al. 2017). Algae are photosynthetic organisms, thus having the ability to convert solar energy and carbon dioxide into biomass and oxygen. They catalyze the dehydration of $\mathrm{HCO}_{3}{ }^{-}$using carbonic anhydrase as compensatory mechanism for $\mathrm{CO}_{2}$. The marine algae mostly assimilate $\mathrm{CO}_{2}$ by the Calvin-Benson cycle (C3), however some species utilize Hatch-Slack cycle to enhance the photosynthetic process (Liu et al. 2021). These oxygenic

V. K. Thakur

School of Engineering, University of Petroleum \& Energy

Studies (UPES), 248007 Dehradun, India

\section{K. Gupta}

Center for Safe and Improved Food, Scotland's Rural College (SRUC), Kings Buildings, West Mains Road, Edinburgh EH9 3JG, UK photosynthetic microbes are diverse in their morphology ranging from unicellular (prokaryotic cyanobacteria) to multicellular (multicellular eukaryotic algae) and their length vary between $0.2 \mu \mathrm{m}$ and $65 \mathrm{~cm}$ existing in about 50,000 algal species (Christaki et al. 2011).

In modern days, immense research attention has been thrown on algae as they are considered a potential feedstock for food, feed, fuel and several other valueadded metabolites. Specific products obtained from algal biomass such as PUFA, essential oils, vitamins, antioxidants, carotenoids and other metabolites are reported to possess remarkable dietary and therapeutic applications (Sathasivam et al. 2019). Algae are largely exploited naturally available food supplements as their cellular composition meets human dietary needs (Koyande et al. 2019a). Despite being a rich source of protein, amino and fatty acids that are ideal for human consumption, aqua and poultry feeds etc., commercial cultivation of algae, more specifically the microalgae began in recent decades, and it still needs enormous research attention (Borowitzka 2018). From an industrial viewpoint, algae used for waste remediation integrated $\mathrm{CO}_{2}$ sequestration to reduce the carbon footprint is an environmentally viable valorisation method. Daneshvar et al. (2022) discussed novel carbon capture techniques and valorisation of carbon sequestered biomass for production of biofuels, oleochemicals and other value added products. Cultivation of algae has an edge over the terrestrial feedstocks as they have higher biomass productivity, higher photosynthetic efficiency, cultivable round the year, and do not require arable land with minimal nutrient inputs (Tan et al. 2020a).

Suitably designed and optimised biorefineries for productivity, energy use and cost for algal biomass valorisation represent a sustainable route to maximise its commercial utilisation (Kumar and Singh 2019). Biomass valorisation determines quantitative and qualitative extraction of value-added metabolites besides making the process cost effective and energy efficient (Gonzalez-Lopez et al. 2020). In this direction, the present review aims to explore the emerging trends and the novel technologies in algal biomass valorisation for extraction of viable products. 


\section{Feed stock potential of algal biomass: an overview}

Algae are envisioned as promising candidates in the renewable energy market as third generation biofuels besides being ideal agents for natural supplements, medicines and feeds. As per the global algae market analysis report 2019-2025, algae market is expected to grow by US $\$ 414.8$ Thousand, guided by a compounded growth of $6.6 \%$. Several microalgae are used to capture atmospheric $\mathrm{CO}_{2}$ with unique carbon concentrating mechanisms and are considered a viable option for greenhouse gas mitigation (Khan et al. 2018). Algal species have formed carbon concentrating mechanisms and can establish themselves in complex waste and pollutants making them lucrative bio-factories for biorefinery approaches (Singh and Dhar 2019). Recent studies reported algal biomass could uptake harmful emission such as $\mathrm{SO}_{\mathrm{x}}$, $\mathrm{NO}_{\mathrm{x}}$ and convert them into valuable by-products (Singh and Thakar 2015). Gendy and El-Temtamy (2013) reported that a $\mathrm{kg}$ of algal biomass can sequester $1.83 \mathrm{~kg}$ of $\mathrm{CO}_{2}$ coupled with effective uptake of other harmful flue gases and nutrient load from complex waste waters.

Bioenergy potentials of algal biomass is the current topic of global research as algal fuels are efficient, fast growing and yield high quality fuel without distressing the food crops. Algal fuels include both liquid fuels (biodiesel, bioethanol) and gaseous fuels (biomethane, biogas) and are renowned in global energy markets as a mighty replacement to conventional fuels (Zabochnicka-Świątek 2010). An increasing demand for algae-based bioethanol and biodiesel as fuel alternatives has been observed in the recent years. Microalgae Chlorococcum infusionum, C. reinhardtii UTEX 90, C. vulgaris and Chlamydomonas reinhardtii are model candidates for large scale bioethanol production that research has identified (Daroch et al. 2013). Macroalgae also possess competent yields and globally exploited for bioethanol. Species of Gracilaria, Undaria and Laminaria have been investigated for bioethanol production via biorefinery routes (Tan et al. 2020b).

Algae are an affluent source of bioactive compounds namely the proteins, amino acids, carotenoids, lipids, fatty acids of dietary value, polysaccharides, auxins etc. Recent studies have identified anti-bacterial, antioxidant, anti-inflammatory, antitumor and antiviral properties, in addition to the established phenomenon that algal biomass itself acts as dietary and nutrient source of food and feed standards (Michalak and Chojnacka 2015). Besides, microalgal and macroalgal metabolites are high value compounds that are used as cosmetics and nutraceuticals. Algal extracts are exploited as anti-ageing compounds, sunscreen agents, moisturisers, emulsifiers etc. (Aslam et al. 2021). Pimental et al. (2018) discussed on the existing commercial cosmetic products from algae namely the carrageenan, Gelcarin ${ }^{\circledR}$ PC 379 , alginate etc., and highlighted that these compounds have been recognised as functional skin care products.

Nutritional value of the algal compounds holds notable industrial value capable of replacing the animal protein and lipid sources in the aquaculture industry (Geada et al. 2021). Though, algal carotenoid is a secondary pigment, yet it possesses therapeutic attributes. Of the different class of carotenoid compounds that exist, $\beta$-carotene and astaxanthin have enormous applications as anti-cancer, anti-inflammatory agents and are used to treat metabolic disorders, gastric ulcers etc. (Sathasivam et al. 2019). Antioxidant properties of Pterocladia sp., Porphyra sp., Fucus nesiculosus and Padina gymnospora have been well documented. The remarkable credentials of algal biomass upsurged its value in global market which parallelly demanded intensive research on cultivation and valorisation methods to attain a sustainable supply chain (Fleita et al. 2015). Figure 1 depicts the feedstock potentials of algal metabolites and its diverse biotechnological applications for value product recovery.

\section{Value-added metabolites from microalgae}

\section{Bioactive proteins}

Algal proteins and amino acids have garnered attention over the last few decades. The biomass contains about $40-60 \%$ of proteins with significant properties making them desirable food and feed replacements (Suganya et al. 2016) (Fig. 2). Food and Agriculture Organization (FAO) adjudged the dietary significance of algal proteins and stated that they have the edge over the "basic conventional food items", which also makes them highly competitive in food and feed market (Becker 2007). Compared to macroalgae, microalgae are highly explored due to its protein and 


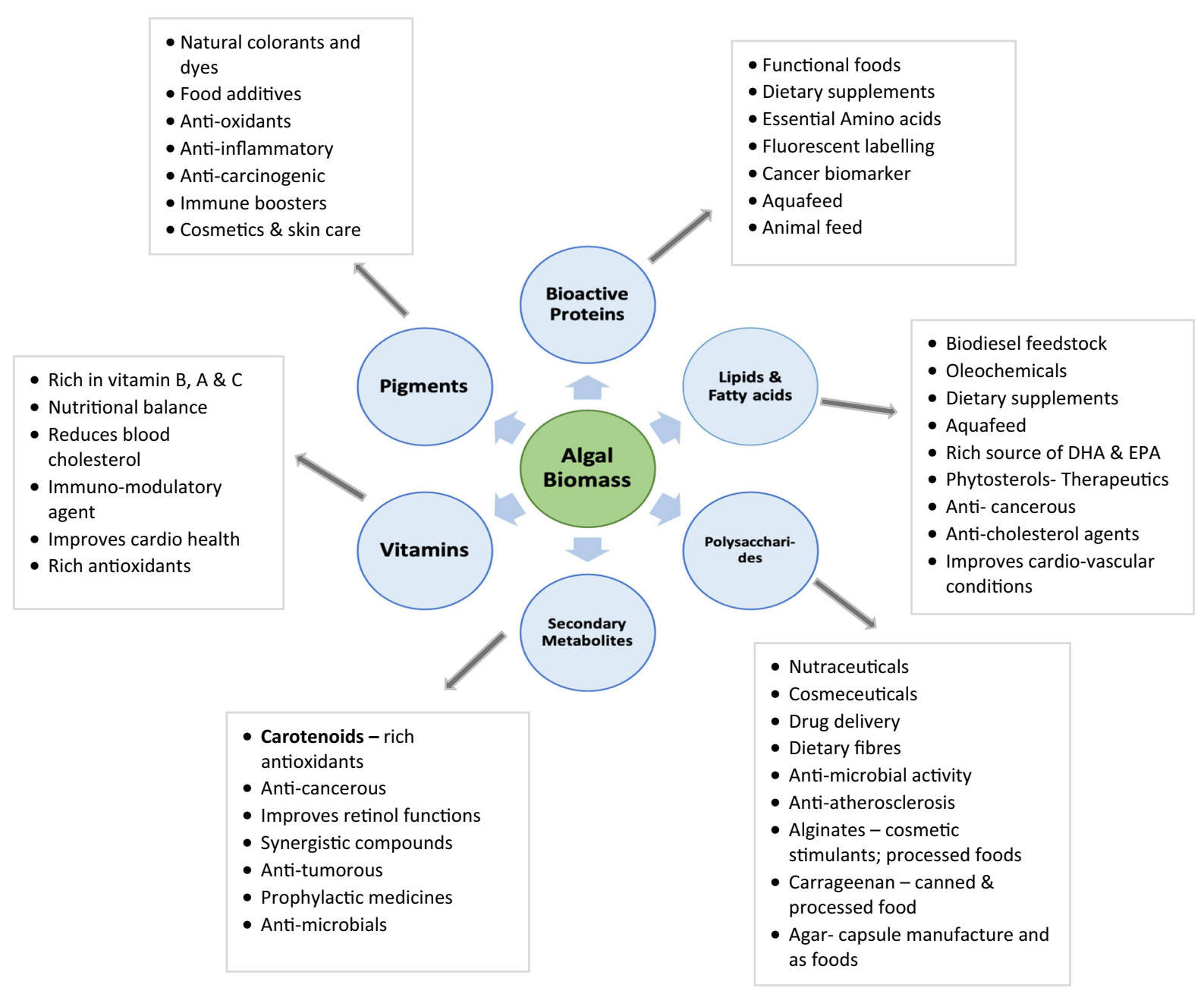

Fig. 1 Feedstock potentials of algal metabolites and its biotechnological applications

amino acid profile with high dietary value. Microalgal species Aphanizomenon sp., Chlorella sp., Dunaliella sp. and Arthrospira sp., with a high protein content of $50 \%$ and above are utilised for human consumption (Koyande et al. 2019a). While other microalgae, namely Tetraselmis sp., Nannochloropsis sp., Dunaliella sp., and Chlamydomonas sp., have shown efficacy as an animal and aquaculture feed (Hashmein et al. 2019; Sousa et al. 2008).

Selected cyanobacteria, Spirulina sp. (45-65\%), Arthrospira maxima (70-75\%), Synechococcus sp. (60-65\%), have also gained research interest due to its rich amino acid composition (Chronakis et al. 2011). Irrespective of the morphotype, algae are an affluent source of essential amino acids including lysine, valine, leucine and tryptophan. In a study conducted by Mišurcová et al. (2014), the RDI (Recommended Daily Intake) of different algal species were compared. Lysine, Leucine, Alanine, Glutathione and Asparagine were dominant in the amino acid pool of selected algae. The RDI of commercially used algae as a source of EAA (essential amino acid composition) were $3 \mathrm{~g}$ (Chlorella pyrenoidosa), $13 \mathrm{~g}$ for Spirulina platensis and Spirulina pacifica respectively. Pereira et al. (2018) experimented on different protein extraction methods and their impact on the protein fractions' quality and quantity to be used as functional foods in Spirulina sp. LEB18. Protein and amino acid concentrates from several Spirulina sp. have been graded as GRAS (Generally Recognised as Safe) by FDA (Food and Drug Administration). Chen et al. (2019) investigated the functional properties of three 


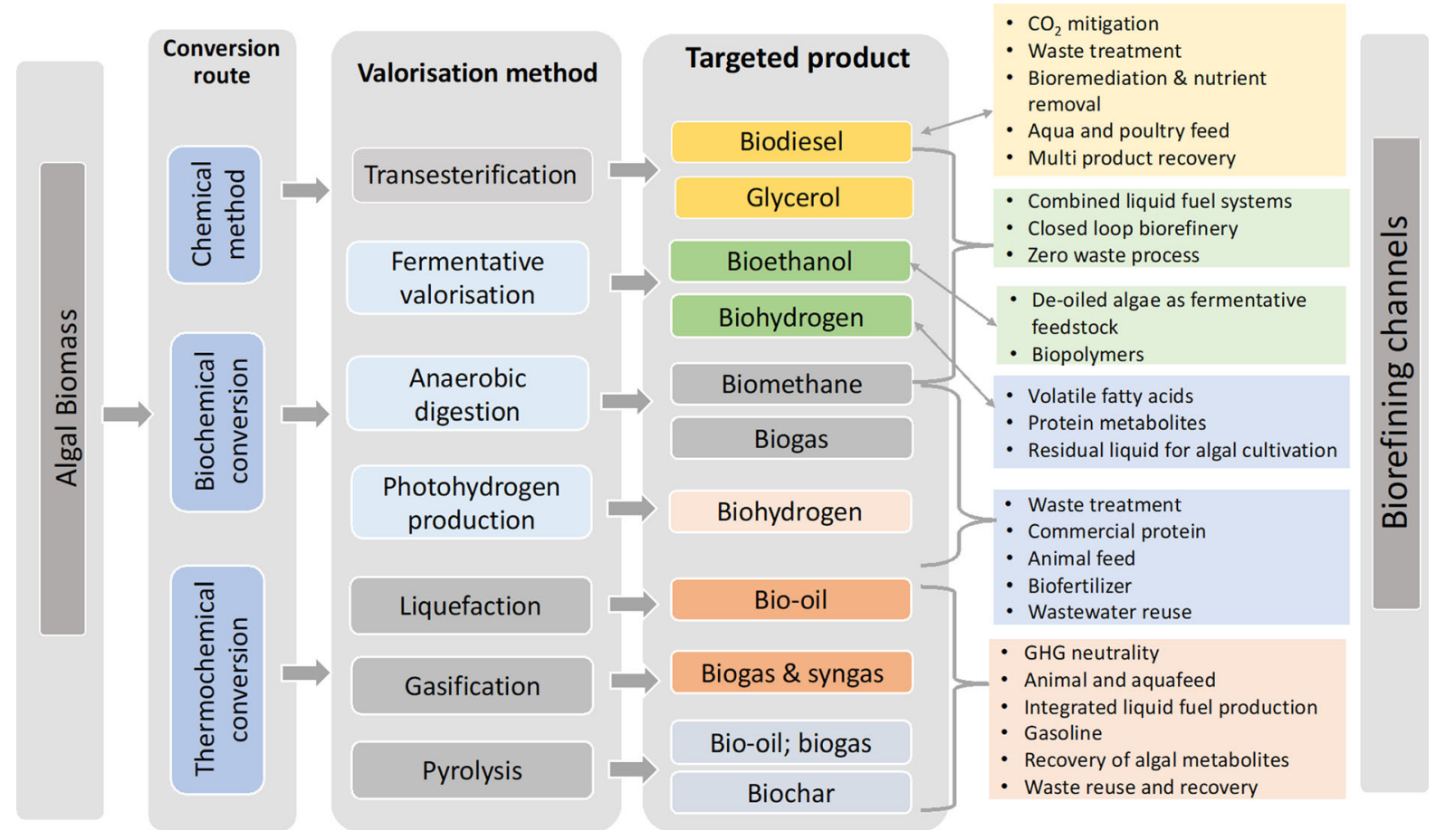

Fig. 2 Biomass valorisation and its plausible biorefinery channels

microalgal species. The study highlighted the importance of the biomass valorisation methods as it could significantly impact the properties of the algal proteins. The vast biodiversity of algae and its habitat distribution is attributed to the substantial differences in its protein and essential amino acid composition (EAA); hence a high throughput screening of a large number of species would enable the identification of novel species with remarkable nutritive value (Dawczynski et al. 2007).

\section{Polysaccharides}

Marine algal polysaccharides (MAP) have immense potential for industrially viable and novel products. They are used in global markets as nutraceuticals, cosmeceuticals, pharmaceuticals, for drug delivery, fertilisers and as aquafeeds (Rajendran 2020). In recent years, MAP's have placed their foot in newer areas of research namely the bioremediation, carbon sequestration and in genetic engineering technology (de Jesus Raposo et al. 2013). Macroalgal polysaccharides, including the fucoidan, ulvan, rhammnan sulfate, and laminarin sulfate of seaweed origin, have found their application as therapeutic agents for atherosclerosis (Patil et al. 2018). Lipid reducing and anti-coagulant properties of laminarin sulfate extracted from brown alga laminaria and carrageenan from red algae are delved into meticulously for commercial applications (Smith et al. 2018; Necas and Bartosikova 2013). Sulphated polysaccharides from microalgae and cyanobacteria show antiviral activity against HIV-1, HSV-1, Flu-A (de Jesus Raposo et al. 2013). Agar, which is the combination of two different polysaccharides agarose and agaropectin extracted from Gelidium sp. and Gracilaria sp. is globally used as texturing agent in foods, while agarose a non-sulphated form of agarose, is used extensively in protein and molecular research (Vavilala and D'Souza 2015).

The complex structural configuration of the MAP is a bottleneck for its sustainable production and its commercial value. The molecular composition of the MAP vary across the algal genera, hence requires a precise valorisation method (Pierre et al. 2019). Jönsson et al. (2020) critically reviewed the impact of the diverse valorisation methods on the quantitative and qualitative profile of the MAP. Enzymatic modification is acclaimed as a plausible method to recover MAP without compromising its intrinsic properties. 
However, the cost efficacy of the enzymatic valorisation process can be improved by aiding on technologically viable platforms such as the combine biomass processing, biorefining etc. Gaignard et al. (2019) detailed the compositional heterogeneity of the algal polysaccharides among the tremendously diverse algal species. Hence, a consensus should arrive on the extraction and purification method specific for algae or the type of MAP in order to widen the commercializing aspect. Total biomass valorisation in a biorefinery approach may be sorted to extract MAP as exopolysaccharides are comprehensively utilised for biomedical applications (Yen et al. 2013).

Lipids, fatty acids and essential oils

Microalgae are a promising source of lipid and fats. Algal lipids are considered a potent third-generation biofuel feedstock; however, they are interesting candidates for dietary fats and supplements and could potentially be the equivalent synthetic products (Kumar et al. 2020b). The vast and varied habitat distribution of algae implicates the diverse cellular lipid composition in these organisms (Uma and Dineshbabu 2020). Microalgae are sustainable sources of essential oils rich in long chain n-3 PUFA (Poly Unsaturated Fatty Acid), omega-3 fatty acids, DHA and EPA along with moderate levels of MUFA (Monounsaturated Fatty Acids) and lesser amounts of SFA (Saturated Fatty Acids) (Remize et al. 2021). The global market size of omega-3 fatty acids in 2017 accounted to be 2.49 billion and is projected to increase by $7 \%$ by 2027 (Omega 3 Report 2020). The surging exigence for the essential fats coupled with the unsustainable availability of conventional sources, algal PUFA and oleochemicals have gained attention as novel alternatives (Harwood 2019). Reports of Batista et al. (2013) and Borowitzka (2013) reported the high value microalgae for PUFA are Chlorella sp., Nannochloropsis sp., Odontella aurita, Parietochloris incise, Phaedactylum tricornutum, Porphyridium cruentum, Diacronema vlkianum, Isochrysis galbana, Schizochytrium sp. Spirulina platensis and Ulkenia sp. Another lucrative class of lipids from algal biomass are the sterols, which primarily includes phytosterol, ergosterol, fucosterol and cholesterol. Algal phytosterols are used as therapeutic steroids, predominantly as anti-cancer and anti-cholesterol agents (Francavilla et al. 2012).
The dietary value of the algal lipids and the bioaccessibility of the long chain PUFA have been studied in copious interventional trials (Cottin et al. 2011). The findings suggest that about $50-100 \%$ of algal DHA and EPA are made available to humans and have significantly improved the cardiovascular conditions. DHASCO-T and DHASCO-S are commercial DHA capsule from Schizochytrium sp. delivered competent levels of nutritive fats in humans (Lane et al. 2014). The bioequivalence algal oils both as capsules (DHASCO) or as fortified foods had a positive effect on the plasma phospholipid and erythrocyte DHA and performed better compared to the synthetic supplements (Arterburn et al. 2007).

Algal biomasses tend to present distinctive bioaccumulation profiles and growth dynamics with the changing environment or in the presence of stressors. Hence, optimisation approach is essential to extract the key metabolites without compromising its dietary value (Laurens et al. 2017). For pilot scale production of algal lipids and fats, it is essential to establish an indepth understanding of algal genomes, biochemical pathways, and organism response to environmental, nutrient stress, and genetic manipulation (Wells et al. 2017; Makatsoris et al. 2019). Phaeodactylum tricornutum with about $30 \%$ omega-3 fatty acid is an industrially claimed algae for human consumption. Hamilton et al. (2015), overexpressed the heterologous genes responsible for PUFA production that enhanced the yield by $7.5 \%$ with an elevated EPA productivity of $43.13 \mathrm{mg} / \mathrm{L}$ in reduced light conditions. Despite the availability of multiple valorisation methods for algal lipids, fermentative technology has been the optimistic method for consumable DHA and EHA (Barclay et al. 2013). Schyzochitrium sp. and Ulkenia sp. were successfully cultured in heterotrophic carbon from valorised by-products that resulted in enhanced DHA content (Gupta et al. 2012). Oliver et al. (2020) reviewed the cultivation strategies of PUFA form algal biomass and suggested that heterotrophic cultivation of algae is cost burdening and unsustainable for DHA production using renewable carbon sources (sugarcane waste, molasses, lignocellulosic biomass) could be a bioeconomic approach. Interestingly, algae are commercially acclaimed as "super foods" and are consumed as whole food (dried biomass) for their dietary and therapeutical benefits. Arthrospira sp. and Chlorella 
sp. are consumed as a dried powder, marketed for its valuable fatty acid rich in $\gamma$-linolenic acid and essential fatty acids. Algal super foods are reported to have anti-tumour and anti-coagulant activities besides acting as a nutrient buffer in the human system (Liu and Hu 2013; Martinez et al. 2018).

\section{Vitamins}

Algae have been in human diet for over decades and are a pivotal source of nutrients in aquatic food web. The biomass potential of algae for its protein, fatty acid and pigment is well established, however recently the vitamin load gathered momentum of research (Buono et al. 2014). Owing to the limited availability of vitamins in vegan diets, algal foods are considered excellent source of folate, vitamin B12 and niacin (Watanabe et al. 2013). The largely cultured algae for the purpose of commercial vitamin-B production are Chlorella pyrenoidosa, Arthrospira platensis and Spirulina sp. Studies of Edelman et al. (2019) affirmed that Chlorella are a rich source of bioactive-folate with rich concentrations of 5-HCO-H4 folate and 5,10$\mathrm{CH}^{+}$-H4 folate. However, the study also highlighted the significance of the extraction methods on the quantity and quality of the recovered folate. Additionally, biomass harvesting, drying, and processing methods may also impact the vitamin's quantity (Jeske et al. 2011).

Watanable et al. (2013) reported the bioavailability of vitamins that are few folds higher in Chlorella sp. while the bioactive pool of the Spirulina sp. are rich in pseudo-vitamin which makes them less ideal for therapeutic applications. Lima et al. (2018), postulated that $\mathrm{B} 12$ binding of the microalgal vitamins in humans could be enhanced by expressing the human B12binding protein intrinsic factor (IF) in their model organism Chlamydomonas reinhardtii. In another report by Andrade et al. (2018) microalgae Spirulina and Chlorella are found to be excellent source of vitamin B (Thiamine-B1, riboflavin-B2, pantothenic acid (B5), folate and cobalamin-B12) and vitamin A ( $\beta$-carotene). Algal vitamins have proven health benefits in human metabolism. Vitamin A from microalgae accelerates the immune function and cellular interaction, while vitamin B3 has been instrumental in cholesterol metabolism, reduces blood glucose and improves cardio-vascular conditions (Solomons 2012). A recent study has identified a marine diatom Skeletonema marinoi that is rich in ascorbic acid and could accumulate large quantities of vitamin C. Being a water-soluble vitamin, it functions as an immuno-modulatory agent. Also, it aids in collagen bio-synthesis (Smerilli et al. 2017).

Microalgae have been identified as reserves of vitamin E and are synthesised from Chaetoceros calcitrans, Nannochloropsis oculate and Dunaliella tertiolecta for biotechnological applications (Santiago-Morales et al. 2018). The specific bioavailable concentration and functional roles of different vitamin rich microalgal bio-factories have been reviewed by Del Mondo et al. (2020). The authors highlighted the technical setbacks and the conundrum that lay ahead in the road map of sustainable vitamin production from algal biomass. Koyande et al. (2019a), critically reviewed the microalgal species that are exploited as a vitamin resource since 1990 and identified the research gaps that exists in development of viable algal vitamin food and feed. The development of algal food capable of delivering fat-soluble vitamin in human system needs better insights to identify industrially competent valorisation methods. Such comprehensive research information on extraction and delivery systems are sparsely available and demands research attention (Ferraces-Casais et al. 2012).

\section{Secondary metabolites}

Algae are a potential feedstock for its versatile secondary metabolites synthesised at a later stage of growth (Fig. 1). Both fresh water and marine algae accumulate large secondary metabolites capacities, including carotenoids, sterols, polyphenols, etc. (Leflaive and Ten-Hage 2007).

\section{Carotenoids}

Carotenoids, the light harvesting pigments are present in aquatic food chain in abundant quantities. Algae, rich in carotenoids and $\beta$ - carotene are exploited for commercial production owing to its rich antioxidant and anti-cancerous properties (Guedes et al. 2011; Takhashi et al. 2015). The other carotenoid derivatives with health benefits are astaxanthin, fucoxanthin and zeaxanthin, all of which are known for scavenging harmful oxygen with appreciable antioxidant values (Galasso et al. 2019). The presence of one or more of these pigments is species specific. The algae that are 
mainly known for its carotenoid abundance are, Dunaliella salina, Nanochloropsis sp., Spirulina platensis, Tetraselmis suecica, Dunaliella tertiolecta and Asterarcys quadricellulare (Singh et al. 2019). The health benefits of the algal carotenoids are abundant; they act as synergistic compounds in preventing cellular damage in cancer patients, repress cardiovascular disorders, reduce cholesterol in blood streams, used as antioxidants and are aidful in retinol functions (Galasso et al. 2019).

\section{Polyphenols}

Polyphenols are an interesting class of compounds with multiple health benefits. Algal polyphenols include phenolic acids, iso-flavonoids, flavonoids, coumarins, lignins, and phenolic polymers (Manach et al. 2004). The vast therapeutic and health attributes of polyphenols include its antioxidant, anti-microbial, and anti-tumoral, anti-cancer, anti-diabetic, anticancer properties that have intrigued the biotechnologist globally (Gastineau et al. 2014). In the macroalgal group, brown algae and seaweed are immensely rich in polyphenols (Fernando et al. 2016). Profound antioxidant property and inhibitory effects of four economic macroalgae were associated with the bioactivity of the phenolics (Yuan et al. 2018). Microalgae on the other hand, possess polyphenols amongst their diverse genera. Higher concentration of polyphenolic acid and flavonoids were reported in Spirogyra sp., Euglena sp., Caespitella pascheri, Nostoc sp., Nodularia spumigena and Arthrospira sp. (JerezMartel et al. 2017). Jimenez-Lopez et al. (2021) reviewed the health benefits of polyphenols and discussed the pros and cons of different extraction methods. The study suggested that algal polyphenolics are not only to be used as therapeutics, but they could be also utilised as prophylactic and palliative care.

\section{Oleochemicals}

Microalgae are plausible feed stock for the value added oleochemicals as these oleaginous algae are a rich source of lipid and fats that contain $\sim 70 \%$ oil by weight (Chisti 2007). Oleochemicals are a class of chemical compounds obtained from fats, lipid and fatty acids and find its application in alternative energy, biosurfactants, lubricants and others ( $\mathrm{Yu}$ et al. 2014).

\section{Biodiesel}

Algal oleochemicals offer sustainable environmental solutions, including green energy (biodiesel) integrated with $\mathrm{CO}_{2}$ sequestration and waste minimisation in a biorefinery approach (Wang et al. 2020). Lipid being a low value compound, is effectively channelled for producing a by-product or a process such as bioremediation, carbon mitigation, while recovery of biodiesel is the primary target. These biotechnologically viable compounds are flexible to genetic and metabolic engineering and can be modified for enhanced performance (Pfleger et al. 2015). Oleochemicals from algal lipids have gained momentum in recent years, as algae are classic chassis framework species for evolution and adaptation and are collaborative towards nutrient optimisation, strain development, and genetic manipulation (Marella et al. 2018). Biodiesel, the liquid fuel from algal lipids is valorised through different conversion technologies namely the transesterification and thermochemical conversion. Being a carbon neutral fuel, algal biodiesel can significantly replace conventional fuel, and the biomass can be utilised to quench harmful greenhouse gases from the atmosphere (Chye et al. 2018). Chlorella sp. are the most commercially used algae for biodiesel production and have been genetically modified for enhanced lipid yield and carbon capture (Mata et al. 2010; Medipally et al. 2015). Table 1 shows the variable lipid content of algal genera and its diverse biotechnological potentials. Bioenergy supply chains could be improvised by the emerging technological platforms, where one or more forms of energy could be processed from the feedstock biomass in a closed loop (Gupta et al. 2014). By this way, algal fuels will become potential candidate in the energy sector with high biorefining values.

\section{Surfactants}

Algal surfactants possess novel structural configuration that suggests the broad scope of its in-situ functional properties for diverse biotechnological applications. Algal lipids, principally the membrane lipids and the monounsaturated fatty acid derivates are ideal source of oleochemicals that are of particular interest as bio-surfactants. Fatty alcohol derivatives namely sulfates, alkoxylates, amines and ether sulfates are versatile surfactants (Pfleger et al. 2015). Algal 
Table 1 Variable lipid content of algal genera and its biotechnological applications

\begin{tabular}{|c|c|c|c|c|}
\hline No. & Name of the algae & $\begin{array}{l}\text { Total Lipid } \\
\text { yield (dry wt) }\end{array}$ & Biotechnological application & References \\
\hline 1 & Chlorella sorokiniana DSR & Up to $83 \%$ & Biofuels and bioremediation & Hena et al. (2015) \\
\hline 2 & Schizochytrium sp. & Up to $80 \%$ & Dietary lipids and biofuels & Sajjadi et al. (2018) \\
\hline 3 & Botryococcus braunii & Up to $75 \%$ & Hydrocarbons & Kleinart and Griehl (2021) \\
\hline 4 & Schizochytrium sp. & $50-77 \%$ & Biofuels and supplements & Schlagermannet et al. (2012) \\
\hline 5 & Botryococcus braunii & $25-75 \%$ & Biofuels & Schlagermannet et al. (2012) \\
\hline 6 & Nannochloropsis sp. & $36-68 \%$ & Biofuels and aquafeeds & Schlagermannet et al. (2012) \\
\hline 7 & Nannochloropsis sp. & $45 \%$ & $\begin{array}{l}\mathrm{CO}_{2} \text { mitigation, commercial } \\
\text { production of pigments and lipids }\end{array}$ & Thawechai et al. (2016) \\
\hline 8 & Nitzschia sp. & $45-50 \%$ & Biofuels & Schlagermannet et al. (2012) \\
\hline 9 & Neochloris oleobundans & $35-45 \%$ & $\mathrm{CO}_{2}$ bio-fixation and biodiesel & Razzak (2018) \\
\hline 10 & Neochloris oleobundans & $35-74 \%$ & Biodiesel & Schlagermannet et al. (2012) \\
\hline 11 & Nannochloropsis sp. & $55 \%$ & Biofuels and aquafeeds & Sajjadi et al. (2018) \\
\hline 12 & Dunaliella sp. ABRIINW-11 & $47 \%$ & Pharmaceutical and aquaculture applications & Gharajeh et al. (2020) \\
\hline 13 & Scenedesmus dimorphis & $10-40 \%$ & Biofuels & Milledge et al. (2011) \\
\hline 14 & Chroothece richteriana & $35 \%$ (PUFA) & Therapeutics and dietary supplements & Aboal et al. (2014) \\
\hline 15 & Monoraphidium contortum & $31.5 \%$ & Liquid biofuels & Bogen et al. (2013) \\
\hline 16 & Chlorella vulgaris & $30 \%$ & Biofuels & Shokravi et al. (2020) \\
\hline 17 & Chlorella variablis & $24 \%$ & Biodiesel & Nirmala ( 2020) \\
\hline 18 & Oscillatoria sp. & Up to $20 \%$ & Biodiesel and biocalcification & Uma et al. (2020) \\
\hline 19 & Spirulina subsalsa & $19 \%$ & Biodiesel & Uma et al. (2020) \\
\hline 20 & Ulva sp. & Up to $15 \%$ & Human Health foods and animal feeds & Moustafa and Batran (2014 \\
\hline
\end{tabular}

oleochemicals derivatives are widely used in industries that produce laundry products, emulsifiers, oil industry, thickeners, foaming agents etc. Kainarbayeva et al. (2019) extracted oleochemicals from three microalgal species, Spirulina sp, Botryococcus $s p$ and a wild strain of the Sugur soda lake culture and evaluated their biosurfactant properties. The study identified that ester exchange using methanol could be a plausible strategy to accelerate the surfactant accumulation in Spirulina sp. The investigation of Radmann et al. (2015) on the cultivation strategies of three microalgal species, spotted carbon source as the key factor that is pivotal in enhancing its surfactant properties. The crucial role of carbon in fatty acid metabolism is explainable and it opens the scope of coupling carbon sequestration with biosurfactant synthesis from lipid rich microalgae. Fatty acids of the crude algal biomass along food hydrolysates were trans esterified and subjected to epoxidation for production of plasticiser and surfactants (Pleissner et al. 2015). Compounding of two conventional methods provides immense opportunities to minimize waste and acquire industrially viable multi-products.

\section{Systemic exploration of recent trends in algal biomass valorisation for fuel production}

Algae is a potential source for valuable products like food, feed, and biofuels for pharmaceuticals, nutraceuticals and cosmetics industries. The integrated valorization approaches help in the extraction of valuable products from algae thus expanding the horizon of bioproducts in the therapeutics and food industry. Sequential extraction of valuable compounds from the algal biorefinery results in minimization of waste, expanding revenue and full utilization of feedstocks. These valorization processes are important to utilize algae as a favourable resource in biorefinery. 
High throughput fermentative valorisation

Algae are a promising renewable feedstock for fermentation which is the productive valorisation method to maximise algal resource recovery as a range of biofuel (e.g., bioethanol) and value-added compounds. Suitable biomass pre-treatment and valorisation methods are essential for maximum hydrolysis of sugar, carbohydrates and biofuels. To fasten the process of high throughput fermentation, the pretreatment and hydrolysis of the biomass must be combined. Novel methods of bio-hydrogen and bioethanol products aim to improvise the fermentation and photolysis processes (Dasgupta et al. 2010). The next generation biofuels, the 4th generation biofuels rely upon novel technological process like "Photofermentation" or combined algal biomass process using genetically modified microalgae for biofuel production through biorefining (Silva and Bertucco 2019). High-throughput fermentation is a novel method for bioethanol as it is a 'zero waste' strategy. El-Dalatony et al. (2019) subjected Chlamydomonas mexicana to successive fermentation process and the residual biomass was transesterified resulting in simultaneous extraction of carbohydrate, protein and lipid extraction. The study affirmed that high throughput fermentation can be implemented to generate other forms of biofuels integrated with bioethanol and can minimise cost involved and waste generation maximally. The fermentative products obtained by serialised valorisation showed similar profile to that of the intact cell extraction processes. Lai et al. (2016) demonstrated a novel bioethanol strategy the "selective fermentation. Microalga Scenedesmus sp. was selectively fermented using granular sludge to yield volatile fatty acids thereby retaining the other metabolites for biotechnological applications. Subhash and Mohan (2014) investigated the plausibility of utilising de-oiled algal biomass as a feedstock for biohydrogen through dark-fermentation using anaerobic mixed microflora as a catalyst. The results affirmed that algal biomass can be successfully fermented to obtain two forms of bio-energy. Xia et al. (2015), reviewed the various modes of high throughput fermentation which includes dark fermentation combined photo-fermentation, anaerobic digestion for biomethane and hydrogen generation from algal biomass. The organic remains (acetates, protein, acetate) that leaves the process following the dark fermentation can be further subjected to a photo fermentation to yield viable fatty acids. In an earlier study by Xia et al. (2013), substantial yields of biohydrogen (144.9 $\mathrm{mL} \mathrm{H}_{2} / \mathrm{g}$ $\mathrm{Vs}$ ) and biomethane (161.3 $\mathrm{mL} \mathrm{CH}_{4} / \mathrm{kJ} / \mathrm{g} \mathrm{Vs}$ ) from Nannochloropsis oceanica using an integrated fermentative reaction was recorded. Anaerobic fermentation of algal biomass releases substantial quantities of volatile fatty acids (VFA) as intermediary compounds, which could in turn be used for large scale cultivation of microalgae in a closed-loop attempt (Kumar et al. 2020a). A novel approach for carbon recycling from microalgal biomass and utilisation of the resultant VFA through thermophilic anaerobic fermentation was attempted by Kim et al. (2019). The integrated biomass valorisation model achieved an accelerated carbon recycling ratio of $\sim 40 \%$ and fatty acid recovery of $60 \%$. High throughput fermentation of algal biomass is an efficient strategy to valorise biomass completely and harness maximum energy cost-effectively.

One step conversion of biomass to metabolites

Biomass valorisation for viable biotechnological products is executed in multiple steps. While biofuel production from algae employs pre-treatments methods, hydrolysis, lipid extraction, transesterification, pyrolysis purification (Fig. 2) etc., However, methods like direct biomass conversion, in-situ transesterification unswervingly converts the biomass into the targeted products bypassing severing pre and post treatment methods. This technological upgrade is profitably put into practice for biofuel processing. Biodiesel extraction from Serratia sp. revealed a onefold increased product recovery in lesser time as compared to the conventional methods (Kumar et al. 2017). Performance efficiency of one step valorisation methods using supercritical methanol was compared with microwave assisted transesterification while the former was found to be superior in being energy efficient and yielding stable biodiesel product with no or minimal impurities (Patil et al. 2012). An integrated biomass deconstruction process was evaluated using a thermophilic bacterium Defluviitalea phaphyphila, capable of assimilating sugars to direct brown algal biomass to bioethanol. The fermentative capacity of the bacterium was utilised via genetic manipulation to enhance the biodiesel production capacity in algae ( $\mathrm{Ji}$ 
et al. 2016). In a novel approach, biomass of Chrococcus sp. was simultaneously harvested and pretreated by a fungal species Aspergillus lentulus in anaerobic condition. The bio flocculating fungal species notably enhanced biomethane production in Chroococcus sp and rapidly solubilised the sugars. One step biomass valorisation approach appears costeffective and simplified the complex harvesting process of algal biomass (Prajapati et al. 2016).

Microwave assisted transesterification is a recent technological movement for direct conversion of whole biomass to biodiesel. Cancela et al. (2012), demonstrated a base assisted-microwave transesterification of three macro algae and observed significant reduction in reaction time ( $3 \mathrm{~min}$ ) as compared to the base- catalysed transesterification method (3-5 h). Microwaves been instrumental in extracting lipid from algal biomass; however, total valorisation of algal biomass via direct transesterification has gained research attention. This avoids the arduous pretreatment methods (Kapoore et al. 2018). One step conversion of microalgal biomass to biofuel through microwave (MW) assisted transesterification has enhanced FAME recovery in Nannochloropsis gaditana. MW aided biodiesel production could be carried out in bioreactors as an integrated one pot bio-process for self-sustained biodiesel production (Menéndez et al. 2014).

Transesterification of biomass to biofuels

Energy is the ultimate face of global economy. With rapid exhaustion of fossil fuels and increasing global warming, alternative energy has gained momentum in recent years. Microalgal biodiesel is a promising third generation feedstock that are produced through transesterification and thermo-chemical routes. However, to accelerate the efficacy of the process, technology driven sophisticated biomass valorisation methods are essential (Park et al. 2015). Conventional transesterification reactions are categorised into acid, base or enzymatic catalytic methods, however recent advances such as the heterogeneous catalysis, microwave or ultrasound assisted and supercritical transesterification methods have significantly upsurged the scope of biodiesel in energy market terms appreciable cost-economy (Hossain, 2019). In-situ extractive and reactive transesterification of microalgal biomass has gained attention due its significantly lower number of process steps that avoid cost intensive steps such as drying of algal biomass and extraction of lipids (Fig. 3).

Nano-technology has ventured into biofuel research and envisioned as a novel approach for closed-loop utilisation of algal biomass. Nanocatalyst has an edge over the other catalyst in being product specific with high catalytic activity (Akubude et al. 2019). Mesoporous nano-particles can extract lipid fractions from microalgal cells without disrupting their cell wall, enhancing its opportunities for multiple applications and near total biomass utilisation as the biomass remains available for bio-processing (Malik and Sangwan, 2012). In a simple reaction, the nano-biocatalyst containing the nano particle are infused into the reaction mixture containing the alcohol and algal biomass. This process is efficient in biodiesel production and leaves the biomass uncompromised (Zhang et al. 2013). Enzyme lipase immobilised on magnetic nanoparticles is a proven technology for biodiesel from algal biomass. Nematian et al. (2020), demonstrated biodiesel production from Chlorella vulgaris using a lipase immobilised nanoparticle catalyst and achieved a recovery rate of $71.9 \%$ biodiesel. The study highlighted the sensitivity and recyclability of the lipase-nanoparticle catalyst with a pronounced performance efficacy to over five times (70\%) against the conventional methods.

The technical complexity of the homogenous transesterification which involves multiple processing steps, slow reaction time and one time usability have been overcome using heterogenous catalyst that are available as solid forms and can be reused. Homogenous transesterification methods involve laborious purification steps and are cost burdening. Heterogenous catalyst can be reused and recovered for sustained utilisation (Faruque et al. 2020) and have a high tolerance for Free Fatty Acid (FFA) with appreciable specificity and longevity (Thangaraj et al. 2019). FAME recovery from two microalgae Chlorella protothecoides and Scenedesmus obliquus were evaluated using molybdenum oxide fixed on a mixed oxide $\mathrm{ZrTiO}$ heterogeneous catalyst to convert the oleic acid fractions to biodiesel specifically. The high methyl oleate content of the algal species chosen for the study revealed pronounced conversion rate of 84 and $35 \%$, respectively. $\beta$-Strontium silicate was tested for algal oil production from Spirulina platensis 


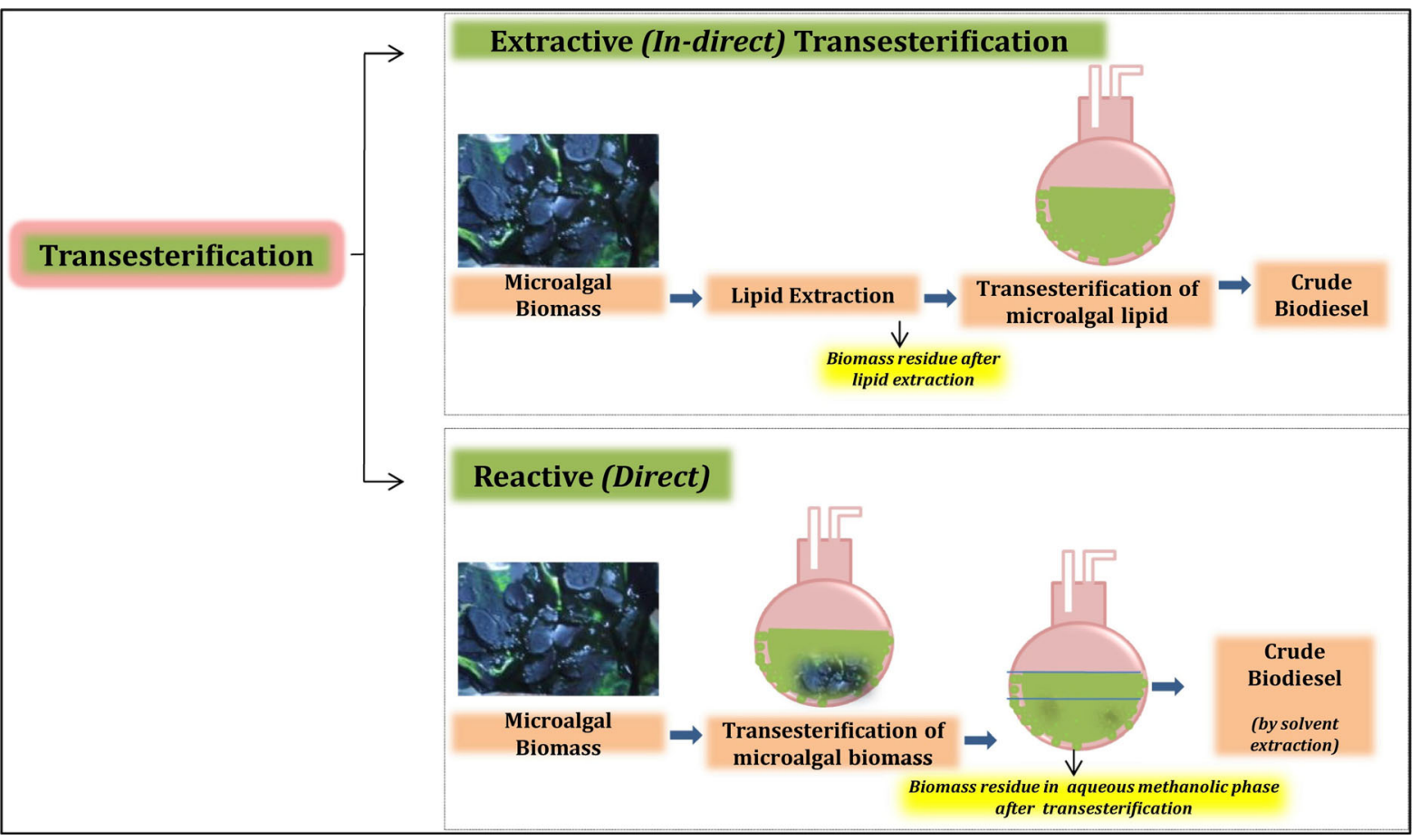

Fig. 3 Transesterification of algal biomass (in-situ). With Permission from Elsevier. Copyright $\subset$ 2021. License Number: 5107730473664 (Karpagam et al. 2021)

and a maximum FAME recovery of $97.8 \%$ was achieved (Singh et al. 2020). Thus, heterogenous catalyst can profoundly valorise algal biomass on a targeted bio-fraction (Veillette et al. 2017). Given its efficient performance, newer heterogenous catalyst and transesterification methods are constantly identified for specific FAME yields.

\section{Anaerobic digestion}

The rich organic load of the microalgae is harnessed to generate biofuels by anaerobic digestion methods (Fig. 2). The biochemical pool of algae constructs them as a valuable anaerobic digestate to be utilised in waste management coupled bioenergy technologies (Stiles et al. 2018). Algal digestate is an immensely useful source of nutrients (Nitrogen, phosphorus and potassium) and have been feedback in a closed-loop approach for large scale algal cultivation to aid the growth of microalgae Chlorella vulgaris (Ras et al. 2011). This approach leaves no biomass residue while significantly shrinks the cultivation cost (Ward et al. 2014). Biodiesel from Tetraselmis suecica was coupled with biomethane production by anaerobic digestion of the residual biomass in the glycerol environment, resulting in an enhanced biomethanation (438.46 $\pm 40.50 \mathrm{~mL}$ ) (Santos-Ballardo et al. 2015). Valorisation of algal biomass for efficient energy recovery could be technically improved using anaerobic hybrid reactor, by coupling other carbon-rich substrates and algal biomass. The complementary substrates (olive mill wastewater) to algae biomass to feed anaerobic digestion not only enhanced the biomethanation process but surpassed the additional biomass pre-treatment methods (Assemany et al. 2018).

Anaerobic digestion (AD) integrated with hydrothermal carbonisation (HC) to convert macroalgal species Fucus serratus and Saccharina latissimi was demonstrated by Brown et al. (2020). Hydrothermal processing at higher temperatures (above $150{ }^{\circ} \mathrm{C}$ ) significantly enhanced the biomethane generation and reduced the net energy demand of the reaction process. A similar effective valorisation method was developed by integrating the $\mathrm{HC}$ and $\mathrm{AD}$ in microalgal consortia, resulting in an enhanced net energy recovery from algal hydro-char and the anaerobic digestion of the residual biomass (Marin-Batista et al. 2019). 
Anaerobic digestion coupled hydro-pyrolysis using algal consortia (Phormidium sp. and Chlorella sp.) resulted in an enhanced (50\%) bio-methanation observed in solid phase hydro-pyrolysis reaction platform. Aqueous pyrolysis accelerated the recovery of nutraceuticals compounds leave no part of the biomass as a residue. In a novel attempt by Llamas et al. (2021) microalgal consortia was used to anerobically digest complex solid waste in a non-convential 2-step valorisation process that resulted in production of short chain fatty-acids (SCFA) and biogas. The biorefining approaches via anaerobic digestion of algae signifies versatility of the biomass potentials for sustainable bioprocess (Choudhary et al. 2020).

Photobiological hydrogen production

Hydrogen production from photosynthetic algae in oxygenic, hypoxic or anoxic conditions have been of particular interest over the last few decades. With the emerging technologies, biohydrogen from algae has attained commercialisation in several parts of the world (Eroglu and Melis, 2011). Despite being a potential renewable energy feedstock, biological $\mathrm{H}_{2}$ production from algal biomass suffers from limiting factors that includes the super sensitivity of the hydrogenase enzyme to $\mathrm{O}_{2}$ molecule, competing metabolic pathways for the photosynthetic reductants and other scaling up challenges which demands improvised technological platforms (Khosravitabar 2019). Bio-hydrogen from algae is produced via two established modes, bio-photolysis (direct and indirect) and photo fermentation. However, recent valorisation methods, namely dark fermentation, immobilisation methods, anaerobiosis, etc., have widened its scope in a commercial prospective (Rashid et al. 2013). Immobilised microalgal cells on a suitable support matrix is envisaged as an ideal choice for pilot scale production of hydrogen from algal biomass as it not only enhances the productivity but is regarded a robust method for pilot plants (Wang et al. 2018). These systems are highly resistant to oxygen sensitivity and can utilise the available light effectively (Kosourov et al. 2018).

A novel biomass valorisation for improved hydrogen using oxysorb-a chemical oxygen scavenger was reported by Khosravitabar and Hippler (2019) in the model organism Chlamydomonas reinhardtii. The mechanism behind a 2-5-fold increased bio-hydrogen generation using oxysorb is that the oxygen scavenger induced anoxia in the culture medium without affecting the PSII activity which further facilitated hydrogen production. Genetic manipulation offered promising solutions for enhanced hydrogen accumulation in algal systems (Nyberg et al. 2015). Usage of microRNA (miRNA) to regulate the PSII genes in Chlamydomonas reinhardtii have been extensively studied. A blue light inducible system was experimented to activate an artificial miRNA which established an optogenic gene regulation targeting the D1 protein in Chlamydomonas reinhardtii. The modified gene overcame the hydrogenase activity setbacks, thereby accelerating the hydrogen accumulation (Wang et al. 2017). A comprehensive review on the emerging approaches in genetic modification for strain development and improved photobiological hydrogen production in microalgae have been studied by Anwar et al. (2019). The model microalgae for biohydrogen, Chlamydomonas reinhardtii, Nannochloropsis sp., Scenedesmus obliquus are flexible to genetic modification and strain development. This could lead coproduction of other forms of bioenergy and other valuable by-products in a refinery platform.

\section{Latest technologies in algal biorefinery: sustainable routes to biomass valorisation}

In recent years algal products have instigated potential ventures for food, medicines, fuels, speciality chemicals, waste management and carbon capture. However, the industry is still in its primitive stages due to the challenges to commercialization which includes its high growth cost, lack of a single harvestation method, strain selection etc., (Awasthi et al. 2020). Despite the bottlnecks in the present scenario, the industry is still booming mainly due to the expanding demand in the global market. Biofuel integrated carbon capture and/ or waste treatment would further will not only minimise the cost but also leaves the process with zero waste. Uses of genetic approaches for strain improvisation ensures that the bio-chemical properties of the selected alga remains constant (Bhalamurugan et al. 2018). Production of multiple products from algal cultivation in a biorefinery process is envisaged as as a promising strategy towards commercialisation. 
Table 2 Emerging trends in algal biomass valorisation and biorefinery potentials

\begin{tabular}{|c|c|c|c|c|c|}
\hline No. & Valorisation method & Organism & Target bio-product & Biorefinery approach & References \\
\hline 1 & $\begin{array}{l}\text { Anaerobic digestion } \\
\text { (AD) }\end{array}$ & $\begin{array}{l}\text { Scenedesmus } \\
\text { obliquus and } \\
\text { Chlorella } \\
\text { vulgaris }\end{array}$ & $\begin{array}{l}\text { A } 14 \% \text { higher biomethane } \\
\text { and waste recovery }\end{array}$ & $\begin{array}{l}\text { I. Waste utilisation } \\
\text { II. Substrate } \\
\text { complementarity }\end{array}$ & $\begin{array}{l}\text { Assemany et al. } \\
\text { (2019) }\end{array}$ \\
\hline 2 & Anaerobic digestion & $\begin{array}{l}\text { Saccharina } \\
\text { latissimi and } \\
\text { Fucus serratus }\end{array}$ & $\begin{array}{l}\text { Enhanced biomethane } \\
\text { recovery of } 185 \mathrm{~mL} \\
\mathrm{CH}_{4} / \mathrm{g} \text { VS at } 150^{\circ} \mathrm{C}\end{array}$ & $\begin{array}{l}\text { Hydrothermal } \\
\text { carbonisation integrated } \\
\text { AD }\end{array}$ & $\begin{array}{l}\text { Brown et al. } \\
(2020)\end{array}$ \\
\hline 3 & Anaerobic digestion & $\begin{array}{l}\text { Chlorella and } \\
\text { Phormidium sp. }\end{array}$ & $\begin{array}{l}\text { A significant } 42 \% \\
\text { biocrude yield and } 200 \\
\mathrm{~mL} / \mathrm{gVS} \text { biomethane }\end{array}$ & $\begin{array}{l}\text { Sequential hydro pyrolysis } \\
\text { integrated } \mathrm{AD}\end{array}$ & $\begin{array}{l}\text { Choudhary et al. } \\
\text { (2020) }\end{array}$ \\
\hline 4 & $\begin{array}{l}\text { Constant magnetic field } \\
\text { applied AD }\end{array}$ & $\begin{array}{l}\text { Cyanoprocayota, } \\
\text { Chlorophyta, and } \\
\text { Bacillariophyceae }\end{array}$ & $\begin{array}{c}\text { Biogas production } 281.1 \mathrm{~L} \\
\text { of biogas } / \mathrm{kg} \text { VS with a } \\
41 \% \text { Biomethane yield }\end{array}$ & Nil & $\begin{array}{l}\text { Dębowski et al. } \\
\text { (2016) }\end{array}$ \\
\hline 5 & $\begin{array}{l}\text { Hydrothermal treated } \\
\text { AD }\end{array}$ & $\begin{array}{r}\text { Microalgal } \\
\text { consortia }\end{array}$ & Biochar and biomethane & $\begin{array}{l}\text { Hydrothermal } \\
\text { carbonization and } \\
\text { anaerobic digestion }\end{array}$ & $\begin{array}{l}\text { Marin-Batista } \\
\text { et al. (2019) }\end{array}$ \\
\hline 6 & $\begin{array}{l}\text { Anaerobic hybrid } \\
\text { reactor }\end{array}$ & $\begin{array}{l}\text { Scenedesmus } \\
\text { obliquus }\end{array}$ & $\begin{array}{l}\text { Enhanced energy } \\
\text { (biomethane) recovery } \\
\text { compared to the pre- } \\
\text { treated biomass }\end{array}$ & Nil & $\begin{array}{l}\text { Assemany et al. } \\
\text { (2018) }\end{array}$ \\
\hline 7 & $\begin{array}{l}\text { Anaerobic digestion of } \\
\text { residual algal cake }\end{array}$ & $\begin{array}{l}\text { Nannochloropsis } \\
\text { sp. }\end{array}$ & $\begin{array}{l}48 \% \text { enhanced methane } \\
\text { yield from wet biodiesel } \\
\text { extracted biomass }\end{array}$ & $\begin{array}{l}\text { Biodiesel coupled } \\
\text { biomethane generation }\end{array}$ & $\begin{array}{l}\text { Kinnunen et al. } \\
\text { (2014) }\end{array}$ \\
\hline 8 & Anaerobic digestion & $\begin{array}{l}\text { Chlorella CG12 } \\
\text { and } \\
\text { Desmodesmus } \\
\text { GS12 }\end{array}$ & $\begin{array}{l}49.87 \% \text { and } 22.26 \% \\
\text { enhanced biomethane } \\
\text { and } 10-12 \% \text { lipid } \\
\text { recovery }\end{array}$ & $\begin{array}{l}\text { Biodiesel recovery } \\
\text { defatted microalgae by } \\
\text { AD }\end{array}$ & $\begin{array}{l}\text { Srivastava et al. } \\
(2020)\end{array}$ \\
\hline 9 & $\begin{array}{l}\text { Anaerobic digestion of } \\
\text { the lipid extraction } \\
\text { biomass by super } \\
\text { critical } \mathrm{CO}_{2} \\
\text { extraction }\end{array}$ & $\begin{array}{l}\text { Isochrysis sp., } \\
\text { Tetraselmis sp., } \\
\text { Scenedesmus } \\
\text { lmeriensis, } \\
\text { Nannochloropsis } \\
\text { gaditana }\end{array}$ & $\begin{array}{l}\text { Enhanced lipid and } \\
\text { methane yield- } \\
\text { Tetraselmis sp. }(11 \% \\
\text { lipid and (236 mL CH4/g } \\
\text { VS methane); S. } \\
\text { almeriensis }(10 \%)\end{array}$ & $\begin{array}{l}\text { Extraction of different } \\
\text { biofuels from algal } \\
\text { biomass }\end{array}$ & $\begin{array}{l}\text { Hernández et al. } \\
\text { (2014) }\end{array}$ \\
\hline 10 & $\begin{array}{l}\text { Biochemical extraction } \\
\text { of lipids, proteins and } \\
\text { pigments and AD of } \\
\text { the residual biomass }\end{array}$ & Chlorella vulgaris & $\begin{array}{l}\text { Methane yield were } \\
\text { consistent with residual } \\
\text { and raw microalgal } \\
\text { biomass (207-237 mL } \\
\mathrm{CH}_{4} / \mathrm{g} \text { volatile solids) }\end{array}$ & $\begin{array}{l}\text { Value added metabolites } \\
\text { and biogas production }\end{array}$ & $\begin{array}{l}\text { Markou et al. } \\
(2020)\end{array}$ \\
\hline 11 & $\begin{array}{l}\text { AD of de-oiled biomass } \\
\text { and co-digestion with } \\
\text { glycerol }\end{array}$ & Tetraselmis suecica & $\begin{array}{l}\text { Enhanced methane yield } \\
\text { from } 173.78 \pm 9.57 \text { to } \\
438.46 \pm 40.50 \mathrm{~mL} \text { of } \\
\text { methane per gram of } \\
\text { volatile solids using } \\
\text { defatted biomass }\end{array}$ & $\begin{array}{l}\text { Residual biomass used for } \\
\text { enhanced biomethane } \\
\text { recovery }\end{array}$ & $\begin{array}{l}\text { Santos-Ballardo } \\
\text { et al. (2015) }\end{array}$ \\
\hline 12 & $\begin{array}{l}\mathrm{Fe} 2 \mathrm{O} 3 \text { nano catalyst } \\
\text { aided } \\
\text { transesterification }\end{array}$ & $\begin{array}{l}\text { Neochloris } \\
\text { oleoabundans } \\
\text { UTEX } 1185\end{array}$ & $\begin{array}{l}\text { Enhanced biodiesel }(81 \%) \\
\text { as compared to } \\
\text { conventional methods } \\
(64 \%)\end{array}$ & $\begin{array}{l}\text { Post biodiesel recovery- } \\
\text { defatted biomass used } \\
\text { for dark-bio-hydrogen } \\
\text { production and bio- } \\
\text { ethanol by AD along } \\
\text { with Saccharomyces } \\
\text { cerevisiae (INVSC-1) }\end{array}$ & $\begin{array}{l}\text { Banerjee et al. } \\
\text { (2019a) }\end{array}$ \\
\hline
\end{tabular}


Table 2 continued

\begin{tabular}{|c|c|c|c|c|c|}
\hline No. & Valorisation method & Organism & Target bio-product & Biorefinery approach & References \\
\hline 13 & $\begin{array}{l}\text { Carbon sequestration } \\
\text { and transesterification } \\
\text { using a bubble } \\
\text { column reaction }\end{array}$ & $\begin{array}{l}\text { Neochloris } \\
\quad \text { oleoabundans } \\
\quad \text { UTEX } 1185\end{array}$ & $\begin{array}{l}\text { Obtained a biodiesel } \\
\text { suitable FAME profile } \\
\text { and sequestered } 1.503 \mathrm{~g} \\
\text { of } \mathrm{CO}_{2} \text { from air }\end{array}$ & $\begin{array}{l}\text { Biodiesel and concomitant } \\
\mathrm{CO}_{2} \text { Sequestration }\end{array}$ & $\begin{array}{l}\text { Banerjee et al. } \\
\text { (2019b) }\end{array}$ \\
\hline 14 & $\begin{array}{l}\text { Direct } \\
\text { transesterification and } \\
\text { acid hydrolysis }\end{array}$ & Chlorella sp. & $\begin{array}{l}\text { FAME yield-256 g/kg- } \\
\text { biomass; coproduction of } \\
\text { sugars, proteins and } \\
\text { pigments }\end{array}$ & $\begin{array}{l}\text { Zero waste biorefinery } \\
\text { approach for biofuel and } \\
\text { fine chemicals }\end{array}$ & $\begin{array}{l}\text { Mandik et al. } \\
\text { (2020) }\end{array}$ \\
\hline 15 & $\begin{array}{l}\text { Carbon capture aided } \\
\text { transesterification }\end{array}$ & $\begin{array}{l}\text { Phormidium } \\
\text { valderianum } \\
\text { BDU20041 }\end{array}$ & $\begin{array}{l}\mathrm{CO}_{2} \text { fixation rate- } \\
56.4 \mathrm{mg} \mathrm{C} / \mathrm{L} / \mathrm{d} ; \mathrm{Lipid} \\
\text { content- } 12.7 \% \text { and bio } \\
\text { calcite removal }\end{array}$ & $\begin{array}{l}\text { Carbon sequestered } \\
\text { biomass for biodiesel } \\
\text { and bio-calcification }\end{array}$ & $\begin{array}{l}\text { Dineshbabu et al. } \\
\text { (2017) }\end{array}$ \\
\hline 16 & $\begin{array}{l}\text { Base catalysed } \\
\text { transesterification } \\
\text { coupled acetone-- } \\
\text { butanol-ethanol } \\
\text { (ABE) fermentation } \\
\text { with different pre- } \\
\text { treatments }\end{array}$ & $\begin{array}{l}\text { Chlamydomonas } \\
\text { reinhardtii CCAP } \\
\text { 11/32 C }\end{array}$ & $\begin{array}{l}\text { Biobutanol recovery- } \\
10.31 \% \mathrm{~g} / \mathrm{g} \text { cdw; } \\
\text { Biodiesel yield-3.82\% } \\
\text { g/g cdw }\end{array}$ & $\begin{array}{l}\text { Bio-butanol and biodiesel } \\
\text { from algal biomass }\end{array}$ & $\begin{array}{l}\text { Figueroa-Torres } \\
\text { et al. }(2020)\end{array}$ \\
\hline 17 & $\begin{array}{l}\text { Enzyme catalysed } \\
\text { direct } \\
\text { transesterification } \\
\text { followed by ethanol } \\
\text { fermentation }\end{array}$ & Scenedesmus sp. & $\begin{array}{l}\text { Total FAME yield-92\%; } \\
\text { bioethanol-86\% and } \\
\text { glycerol recovery-93\% }\end{array}$ & $\begin{array}{l}\text { Algal feedstock for } \\
\text { multiproduct recovery }\end{array}$ & $\begin{array}{l}\text { Sivaramakrishnan } \\
\text { and } \\
\text { Incharoensakdi } \\
\text { (2018) }\end{array}$ \\
\hline 18 & $\begin{array}{l}\text { Dark fermentation for } \\
\text { biohydrogen } \\
\text { production }\end{array}$ & $\begin{array}{l}\text { Mixed microalgal } \\
\text { consortia }\end{array}$ & $\begin{array}{l}\text { Significant enhancement } \\
\text { in biohydrogen yield }\end{array}$ & $\begin{array}{l}\text { De-oiled algal biomass } \\
\text { (DAB) for bio-hydrogen } \\
\text { and recovery of volatile } \\
\text { fatty acids }\end{array}$ & $\begin{array}{l}\text { Subhash and } \\
\text { Mohan (2014) }\end{array}$ \\
\hline 19 & $\begin{array}{l}\text { Algal fermentation of } \\
\text { de-oiled algal biomass } \\
\text { (DAB) with hybrid } \\
\text { pre-treatment (PT) } \\
\text { method }\end{array}$ & $\begin{array}{l}\text { Chlorella sp. and } \\
\text { Scenedesmus sp. }\end{array}$ & $\begin{array}{l}\text { Higher sugar yield in } \\
\text { hybrid PT-0.590 g/g } \\
\text { DAB } \\
\text { Biopolymer PHB- }-0.43 \pm \\
0.20 \mathrm{~g} \mathrm{PHB} / \mathrm{g} \mathrm{DCW}\end{array}$ & $\begin{array}{l}\text { Bioethanol and } \\
\text { biopolymer production } \\
\text { in a biorefinery } \\
\text { framework from DAB }\end{array}$ & $\begin{array}{l}\text { Kumar et al. } \\
\text { (2019) }\end{array}$ \\
\hline 20 & $\begin{array}{l}\text { Acid and alkali } \\
\text { catalysed } \\
\text { transesterification } \\
\text { coupled anaerobic } \\
\text { fermentation }\end{array}$ & $\begin{array}{l}\text { Padina } \\
\quad \text { tetrastromatica }\end{array}$ & $\begin{array}{l}\text { Recovery rate- }-7.8 \% \\
\text { biodiesel and } 83.4 \% \\
\text { bioethanol }\end{array}$ & $\begin{array}{l}\text { Integrated biofuel } \\
\text { generation from marine } \\
\text { macroalgae }\end{array}$ & $\begin{array}{l}\text { Ashokkumar et al. } \\
\text { (2017) }\end{array}$ \\
\hline 21 & $\begin{array}{l}\text { Valorisation of } \\
\text { industrial waste and } \\
\text { industrial flue for } \\
\text { algal biomass } \\
\text { production }\end{array}$ & Chlorella vulgaris & $\begin{array}{c}\text { Enhanced nutrient removal } \\
\text { up to } 75 \% \text {; up tp } 5 \% \mathrm{CO}_{2} \\
\text { captured, elevated lipid } \\
\text { accumulation up to } 34 \%\end{array}$ & $\begin{array}{l}\text { Waste mitigation coupled } \\
\text { carbon sequestration }\end{array}$ & $\begin{array}{l}\text { Yadav et al. } \\
(2019)\end{array}$ \\
\hline 22 & $\begin{array}{c}\text { Individual valorisation } \\
\text { of algal metabolites }\end{array}$ & $\begin{array}{l}\text { Sargassum } \\
\quad \text { muticum-Brown } \\
\text { algae }\end{array}$ & $\begin{array}{l}\text { I. Supercritical fluid } \\
\text { extraction with } \mathrm{CO}_{2}- \\
\text { bioethanol generation } \\
\text { II. Hydrothermal } \\
\text { processing-for } \\
\text { extraction of fucoidan } \\
\text { and phlorotannin } \\
\text { compounds }\end{array}$ & $\begin{array}{l}\text { Various valorisation } \\
\text { process for extraction of } \\
\text { viable biotechnological } \\
\text { products in a biorefinery } \\
\text { viewpoint }\end{array}$ & $\begin{array}{l}\text { Balboa et al. } \\
\text { (2015) }\end{array}$ \\
\hline
\end{tabular}


Table 2 continued

\begin{tabular}{|c|c|c|c|c|c|}
\hline No. & Valorisation method & Organism & Target bio-product & Biorefinery approach & References \\
\hline 23 & $\begin{array}{l}\text { Waste treatment and } \\
\text { lipid production }\end{array}$ & $\begin{array}{l}\text { Ascochloris sp. } \\
\text { ADW007 }\end{array}$ & $\begin{array}{l}\text { I. Up to } 80 \% \text { clean } \\
\text { odourless water with } \\
\text { reduced COD obtained } \\
\text { II. Enhanced lipid } \\
\text { productivity }\end{array}$ & $\begin{array}{l}\text { Bioremediation of dairy } \\
\text { waste and lipid recovery } \\
\text { in a biodiesel viewpoint }\end{array}$ & $\begin{array}{l}\text { Kumar et al. } \\
\text { (2019) }\end{array}$ \\
\hline 24 & $\begin{array}{l}\text { Effluent treatment of } \\
\text { Palm Oil Mill effluent } \\
\text { and biomass } \\
\text { production for } \\
\text { industrial applications }\end{array}$ & $\begin{array}{l}\text { Scenedesmus sp. } \\
\text { and Chlorella } \mathrm{sp.}\end{array}$ & $\begin{array}{l}\text { I. Integrated system } \\
\text { showed pronounced } \\
\text { nutrient uptake and } \\
\text { carbon capture } \\
\text { II. Lipid profile ideal for } \\
\text { industrial usage }\end{array}$ & $\begin{array}{l}\text { Bioremediation, carbon } \\
\text { capture and exploitation } \\
\text { of biomass-closed loop } \\
\text { approach }\end{array}$ & Hariz et al. (2019) \\
\hline 25 & $\begin{array}{l}\text { Enhanced protein } \\
\text { recovery using pulse } \\
\text { electric field cyclic } \\
\text { protein extraction }\end{array}$ & Chlorella vulgaris & $\begin{array}{l}\text { Extracted free protein } \\
\text { during cultivation-96.6 } \\
\pm 4.8 \%\end{array}$ & $\begin{array}{l}\text { A closed loop-biorefinery } \\
\text { approach by continuous } \\
\text { extraction of protein in } \\
\text { the cultivation phase }\end{array}$ & $\begin{array}{l}\text { Buchmann et al. } \\
\text { (2019) }\end{array}$ \\
\hline
\end{tabular}

Biorefinery is a sustainable approach to exploiting every component of biological feedstock to develop one or more products or processes in an energyefficient manner (Koyande et al. 2019b). Microalgal biorefinery is a promising solution for environmental concerns such as atmospheric pollution, fossil fuel depletion coastal pollution etc. These modern technological processes functions towards blue-bioeconomy, by remarkably reducing the cost of algal biomass processing while leading to comprehensive utilisation of the metabolites (González-Delgado and Kafarov 2011). To further enhance the economic viability of the algal biorefinery, closed loop approaches aim at total energy recovery coupled with extraction of biotechnologically viable substances in a food, feed and fine chemical viewpoint (Mohan et al. 2019). Algae are bio-cell factories of intra and extra cellular metabolites and are excellent sources of PUFA, pigments, antioxidants, oleochemicals, polysaccharides, proteins and biofuels. The valorisation and pretreatment methods of algal biomass, which includes anaerobic digestion, fermentation, thermo-chemical liquefaction, and transesterification, can be integrated or further channelled to bio-processes as bio-remediation, carbon sequestration, bio-methanation etc. for in biorefining platform. The versatility of algae that makes the whole biomass made available unlike the other biological feedstocks signifies in holistic position in bioeconomy framework (Mohan et al. 2019). Table 2 highlights the significance of the advancements in the valorisation technology platform and the widening scopes for algal biorefinery.

Algal biofuels are established channels to develop biorefinery and have gained industrial momentum in the recent years. Co-production of other biofuels has been explored using the model organisms Chlamydomonas reinhardtii and Scenedesmus obliquus in a biorefinery perspective as they hold strong literature values. The unique carbon concentrating mechanisms of the microalgae come in play when grown in a flue gas environment. Singh et al. (2014) investigated carbon recycling and biodiesel recovery from an endolithic cyanobacterium Leptolyngbya sp., which successfully created biorefinery venues. With proven results in laboratory platforms for biorefining, a novel industrial site which coupled carbon sequestration of industrial flue gas and biocalcification was demonstrated by Dinesh babu et al. (2017). Cyanobacterium Phormidium sp., revealed growth for 10 days in unscrubbed flue gas and passed out with a pronounced $\mathrm{CO}_{2}$ fixation rate of $56.4 \mathrm{mg} \mathrm{C} / \mathrm{L} / \mathrm{d}$. While FAME profile of the carbon captured cyanobacterial biomass proved to be an ideal candidate for biodiesel with presence of favourable fatty acid profile (C14-C18). A number of such emerging trends in algal biorefinery including anaerobic digestion combined bioremediation, bioenergy integrated nutrient removal, waste treatment, carbon sequestration was critically reviewed (Veerabadhran et al. 2021; Milledge et al. 2019). However, the key driver behind a 
successful algal biorefinery model is the strain identification and speciation via extensive literature study, molecular characterisation and high throughput screening methods to identify the potent alga with intrinsic commercial value and appreciable productivities. A profound understanding of the competent strain and its built-in biomass dynamics, compatibility to optimisation and multiple processing routes are inevitable for biorefining and cost management of algal bio-processes. Fractional pathways and combined algal processing (CAP) are competent technologies that empowers biomass valorisation in developed or modified strains (Laurens et al. 2017). Fractionation of biomass can bring upon multiple channels for biorefinery based on biofuels and essential metabolites such as the oleochemicals, polymers, bioplastics, surfactants, etc. While, combined algal biomass processing aims at extracting a specific product without compromising the quality and quantity of the co-metabolites thereby leaving the residual biomass for further processing (Dong et al. 2016). The existing investigations on algal biorefinery suggest that algae are self-sustainable microbial cell factories and could promote mankind a step closer towards blue-bioeconomy.

Integration of an algal biorefinery to the circular economy

The metabolic and genetic versatility of algae enables downstream processing of a single product to a multiproduct biorefinery in a closed loop modus, which further enhances the refining process's environmental sustainability and economic viability (Mohan et al. 2019). Biorefining in algal systems can be hastened by integrating the pre-treatment and extraction methods with the state-of-the-art technologies like integrated downstream processing, integrated multi-product extraction, combined algal biomass processing etc. (Vermuë et al. 2018). A positive bioeconomy model using algae is further strengthened by techno-economical assessments and Life Cycle Assessments (LCA) to produce bulk products at a reduced cost pro-rata to the market size (Ruiz et al. 2016). Techno-economic assessments and pilot scale data generation are indispensible for industrial microalgal biorefinery processes as production of targeted products are not economically viable and technologically sound (Subash et al. 2022).
Microalgae Chlorella sp. and Scenedesmus sp. were employed in numerous closed-loop biorefinery models (Mohan et al. 2019). Resource-circular algal biorefining was achieved by integrating biofuel, bio-fertiliser and biogas co-production from microalgae cultivation in sugarcane waste and the $\mathrm{AD}$ of residual algal biomass. Process integration notably upsurged the annual production rate of algal biofuel and biogas while cutting down the production costs (Zewdie and Ali 2020).

Waste utilisation and algal biomass valorisation is considered promising to attain value added metabolites in an energy efficient manner. Avila et al. (2022) evaluated mono and co-digestion methods to remediate winery waste in a circular bioeconomy perspective. Comprehensive waste utilisation and minimisation can be achieved in co-digestion methods where the treated water and the dried residual contents can be used for irrigation and as plant fertilizer respectively. Mixotrophic cultivation of high lipid yielding algae in waste streams is a plausible course to circular economy via carbon capture (Arun et al. 2020). Yin et al. (2018) demonstrated DHA production from Schizochytrium sp. cultured in fermentative and microbial waste. The method minimised waste and upsurged the lipid $(63.63 \mathrm{~g} / \mathrm{L})$ and DHA $(28.45 \mathrm{~g} / \mathrm{L})$ yields. A seaweed biorefinery investigation conducted by an Irish macroalgal processing plant revealed augmented scope for circular economy approach with appreciable yields for biogas and biotechnology viable metabolites from Laminaria sp. and Fucus sp. (Tedesco and Stokes 2017). The key factor for success of bluebioeconomy is sustainability, which indeed relies on novel biological feedstocks and the advanced valorisation methods looped into biorefinery by effective integration of the product recovery and waste management (Fig. 2). Algae are definitely an untapped source for viable products however it demands the intersection of technology and academia to achieve eco-friendly and superior products.

\section{Future trends and applications in potential food/ agriculture/pharma fields}

Algae are promising feedstocks for commercial production of viable metabolites that could potentially replace synthetic food and feed supplements. These viable compounds possess wide applications over an 
array of agricultural, pharmaceutical, plastics and polymers, cosmeceuticals, nutraceuticals and oleochemical industries. High value products from microalgae are markedly used as pharmaceutical compounds. $\beta$-Carotene, PUFA and zeaxanthin hold significant value in pharmaceutical industry. $\beta$ Carotene from algal biomass are an emerging vitamin-A supplement, besides being used as 'anti-cancer agents'(Bhalamurugan et al. 2018). Cyanovirin produced by Nostoc sp., is globally used to treat HIV sumptoms and are used as a potent anti-viral agent (Bhattacharjee et al. 2016). High value proteins namely the $\beta$-insulin, $\operatorname{IgA}$, erythropoietin extracted from Chlamydomonas reinhardtii are cultured for production of pharmaceutical proteins. Chlorella and Chlamydomonas are the largely used algae for pharmaceutical purposes (Santhosh et al. 2016). Modern algal biomass valorisation methodologies have fastened the way out for global algal industries to produce sustainable, environment friendly, zero waste, cost effective products. Literally, algal biomass can venture into various agricultural and biotechnological industries that manufacture viable products for humans and other living forms. Their state in the global energy market is growing every year which shows immense potentials for green technologies (Piwowar 2020). In recent years, advanced technologies namely the synthetic biology, combined algal biomass processing, phenomics and Industry 4.0 approach etc., play phenomenal roles in improvising the algal metabolites (Fabris et al. 2020). Industry 4.0 applies machine to machine, plug and play technologies in what is called as "Internet of Things (IoT)" approach (Tao et al. 2018). These advanced methods are called the "digital twin" and makes simulations for the real time data trajectories such that the demand and the yield match exactly and leaves no cost on over production of target compounds (Uhelmann et al. 2017). Despite being highly flexible to genetic modifications, and versatile in its habitat distribution, the practicality of utilising algal biomass in an industrial perspective relies on its processing technology on a green platform with an appreciable scale transfer ration. Additionally, global production of algal products needs to be supported by universal regulation or standards that governs the commercial production of algal metabolites for various applications (Bernal et al. 2011).
The feedstock potentials of algal biomass and its vast applications have been discussed in the earlier sections of this article. List of industrial made algal products as dietary supplements, nutraceutical and therapeutical compounds are presented in Table 2. With newer technologies such as use of hydrothermal systems, accelerates the scope of algal biorefinery and supports superlative product recovery (Morales-Contreras et al. 2022). With the present rate at which algal industry is growing, it is expected to channel positively to attain blue bio-economy backed up by its land free cost-effective cultivation methods (Ullmann and Grimm 2021). The way ahead has purely relied on algal biorefining and continuous research and development activities by national and internationally funded research programs, which would in turn transform the laboratory technologies to land for sustainable algal products.

Global market view of the value added products from algae

Global demand for algal products is growing rapidly owing to the vast and varied benefits of the algal metabolites. Presently, the microalgal market is fragmented, as the industry has recently gained momentum and is undergoing periodic transition in terms of collaboration, newer technologies, addition of novel products etc., The global demand for algal products is mainly attributed to health and dietary products, pharma and neutraceutical industry and biofuels in recent years. According to published reports of "Global forecast to 2028", the market value for microalgal products is expected to reach a maximum of 1.8 billion by the year 2028. The CAGR growth from 2021 is projected to be $10.3 \%$ (Meticulous research ${ }^{\circledR}$, https://www.globenewswire.com/en/newsrelease/2021/09/13/2295918/0/en/Microalgae-Marketis-Expected-to-Reach-1-8-Billion-by-2028-Market-SizeShare-Forecasts-Trends-Analysis-Report-with-COVID19-Impact-by-Meticulous-Research.html). Of the several industrially significant algal species that research has identified, Spirulina holds the major contribution in the global market owed to its immense health benefits to mankind and is so far the predominantly used species in aquaculture industry. An article published in Business insider (2014), acknowledged algae as the super food and these slimy organisms are expected to be the major contributor in the global 
market (health, pharma, cosma and neutraceutical industry) by the year 2025 and would instigate the largest movement towards "circular- bioeconomy".

\section{Conclusions}

With the exalting civilisation, mankind has realised the significance of products obtained from natural feedstocks. When renewability becomes a crucial factor for the commercial production of food, feed and fuel, algal biomass holds a prominent standpoint in the global market. This comprehensive review conceptualises the emerging trends and the state of art technologies in the algal biomass valorisation for novel biotechnological products. We have attempted to enlist the latest technological advancements, novel valorisation methods that has taken the algal biorefinery framework a step closer toward the blue-bioeconomy. The key steps involved in enhancing the efficacy of biomass valorisation are (a) understanding of the algal strains by biochemical and synthetic methods to its true potentials and novelties, (b) simplified pretreatments, integrated extraction and downstream processing (c) one step conversion technologies for maximum valorisation. We envision that merging of the existing valorisation methods with the newer technologies which could enhance the market scope of the algal products with reduced cost and enhanced sustainability. The economics of the algal biorefining could be accelerated by integrated algal processing and closed circular approaches that would bring in "zero waste", "carbon neutral" algal technologies. A sustainable circular bioeconomy will effectively replace the synthetic metabolites and nutraceuticals and could overcome the deficits of the land-based crops when it comes to renewability. Above all, algae can offer promising solutions to environmental concerns by producing clean zero sulphur, carbon neutral renewable fuels, while successively capable of degrading complex waste streams and mitigating climate change by sequestering atmospheric $\mathrm{CO}_{2}$ and industrial $\mathrm{CO}_{2}$ emissions. Research and development in algal valorisation methods would take the trajectory towards complete harvesting of the rich biochemical pool of algae. Future research in algal biomass valorisation need to be focused on diminishing the capital burden of cultivating algae and waste recycling. Holistic extraction of value added metabolites and utilisation of complex waste loadings and gaseous substances is imperative. This review systematically collates the latest trends on algal biomass valorisation and the plausible approaches to overcome the bottlenecks in algal biorefineries.

Open Access This article is licensed under a Creative Commons Attribution 4.0 International License, which permits use, sharing, adaptation, distribution and reproduction in any medium or format, as long as you give appropriate credit to the original author(s) and the source, provide a link to the Creative Commons licence, and indicate if changes were made. The images or other third party material in this article are included in the article's Creative Commons licence, unless indicated otherwise in a credit line to the material. If material is not included in the article's Creative Commons licence and your intended use is not permitted by statutory regulation or exceeds the permitted use, you will need to obtain permission directly from the copyright holder. To view a copy of this licence, visit http://creativecommons.org/licenses/by/4.0/.

\section{References}

Aboal M, González-Silvera D, Roldán M, Hernández-Mariné M, López-Jiménez J, Whitton BA (2014) The freshwater alga Chroothece richteriana (Rhodophyta) as a potential source of lipids. Food Chem Food chemistry 162:143-148

Akubude VC, Nwaigwe KN, Dintwa E (2019) Production of biodiesel from microalgae via nanocatalyzed transesterification process: A review. Mater Sci Energy Technol Materials Science for Energy Technologies 2(2):216-225

Andrade LM, Andrade CJ, Dias M, Nascimento C, Mendes MA (2018) Chlorella and spirulina microalgae as sources of functional foods. Nutraceuticals, and Food Supplements. MOJ Food Process Technol 6(1):45-58

Anwar M, Lou S, Chen L, Li H, Hu Z (2019) Recent advancement and strategy on bio-hydrogen production from photosynthetic microalgae. Bioresour Technol 292:121972

Arterburn LM, Oken HA, Hoffman JP, Bailey-Hall E, Chung G, Rom D, McCarthy D (2007) Bioequivalence of docosahexaenoic acid from different algal oils in capsules and in a DHA-fortified food. Lipids 42(11):1011

Arun J, Gopinath KP, SundarRajan P, Felix V, JoselynMonica M, Malolan R (2020) A conceptual review on microalgae biorefinery through thermochemical and biological pathways: bio-circular approach on carbon capture and wastewater treatment.Bioresour. Technol. Reports100477

Ashokkumar V, Salim MR, Salam Z, Sivakumar P, Chong CT, Elumalai S, Ani FN (2017) Production of liquid biofuels (biodiesel and bioethanol) from brown marine macroalgae Padina tetrastromatica Energy Convers Manag 135:351-361

Aslam A, Bahadar A, Liaqat R, Saleem M, Waqas A, Zwawi M (2021) Algae as an attractive source for cosmetics to counter environmental stress.Sci. Total Environ. Sci. Total Environ.144905 
Assemany P, de Paula Marques I, Calijuri ML, da Silva TL, Reis A (2018) Energetic valorisation of algal biomass in a hybrid anaerobic reactor. Environ Manag Today 209:308-315

Assemany P, de Paula Marques I, Calijuri ML, Reis A (2019) Complementarity of substrates in anaerobic digestion of wastewater grown algal biomass.Waste and Biomass Valorization, 1-12

Avila R, Justo Á, Carrero E, Crivillés E, Vicent T, Blánquez P (2022) Water resource recovery coupling microalgae wastewater treatment and sludge co-digestion for biowastes valorisation at industrial pilot-scale. Bioresour Technol 343:126080

Awasthi MK, Sarsaiya S, Patel A, Juneja A, Singh RP, Yan B, Taherzadeh MJ (2020) Refining biomass residues for sustainable energy and bio-products: An assessment of technology, its importance, and strategic applications in circular bio-economy. Renew Sustain Energy Rev 127:109876

Balboa EM, Moure A, Domínguez H (2015) Valorization of Sargassum muticum biomass according to the biorefinery concept. Mar Drugs 13(6):3745-3760

Banerjee S, Rout S, Banerjee S, Atta A, Das D (2019a) $\mathrm{Fe}_{2} \mathrm{O}_{3}$ nanocatalyst aided transesterification for biodiesel production from lipid-intact wet microalgal biomass: A biorefinery approach. Energy Convers Manag 195:844-853

Banerjee S, Singh H, Das D, Atta A (2019b) Process optimization for enhanced biodiesel production by Neochloris oleoabundans UTEX 1185 with concomitant $\mathrm{CO}_{2}$ sequestration. Ind Eng Chem Res 58(35):15760-15771

Barclay W, Apt K, Dong XD (2013) Commercial production of microalgae via fermentation. Handbook of microalgal culture: applied phycology and biotechnology. Blackwell, Chichester, pp 134-145

Batista AP, Gouveia L, Bandarra NM, Franco JM, Raymundo A (2013) Comparison of microalgal biomass profiles as novel functional ingredient for food products. Algal Res 2(2): 164-173

Becker EW (2007) Micro-algae as a source of protein. Biotechnol Adv 25(2):207-210

Bermúdez Menéndez JM, Arenillas A, Menéndez Díaz J, Boffa L, Mantegna S, Binello A, Cravotto G (2014) Optimization of microalgae oil extraction under ultrasound and microwave irradiation. J Chem Technol Biotechnol 89(11):1779-1784

Bernal J, Mendiola JA, Ibáñez E, Cifuentes A (2011) Advanced analysis of nutraceuticals. J Pharm Biomed Anal 55(4):758-774

Bhalamurugan GL, Valerie O, Mark L (2018) Valuable bioproducts obtained from microalgal biomass and their commercial applications: A review. Environ Eng Res 23(3):229-241

Bhattacharjee M (2016) Pharmaceutically valuable bioactive compounds of algae. Asian J Pharm Clin Res 9:43-47

Bogen C, Klassen V, Wichmann J, La Russa M, Doebbe A, Grundmann M, Mussgnug JH (2013) Identification of Monoraphidium contortum as a promising species for liquid biofuel production. Bioresour Technol Bioresource technology 133:622-626
Borowitzka MA (2013) High-value products from microalgaetheir development and commercialisation. J Appl Phycol 25(3):743-756

Borowitzka MA (2018) Microalgae in medicine and human health: A historical perspective. In Microalgae in health and disease prevention: Academic Press. 195-210

Brown AE, Finnerty GL, Camargo-Valero MA, Ross AB (2020) Valorisation of macroalgae via the integration of hydrothermal carbonisation and anaerobic digestion. Bioresour Technol 312:123539

Buchmann L, Brändle I, Haberkorn I, Hiestand M, Mathys A (2019) Pulsed electric field based cyclic protein extraction of microalgae towards closed-loop biorefinery concepts. Bioresour Technol 291:121870

Buono S, Langellotti AL, Martello A, Rinna F, Fogliano V (2014) Functional ingredients from microalgae. Food Funct 5(8):1669-1685

Cancela A, Maceiras R, Urrejola S, Sanchez A (2012) Microwave-assisted transesterification of macroalgae. Energies 5(4):862-871

Chen Y, Chen J, Chang C, Chen J, Cao F, Zhao J, Zhu J (2019) Physicochemical and functional properties of proteins extracted from three microalgal species. Food Hydrocoll 96:510-517

Chisti Y (2007) Biodiesel from microalgae. Biotechnol Adv 25(3):294-306

Choudhary P, Malik A, Pant KK (2020) Exploration of a novel biorefinery based on sequential hydropyrolysis and anaerobic digestion of algal biofilm: a comprehensive characterisation of products for energy and chemical production. Sustain Energy Fuels 4(3):1481-1495

Christaki E, Florou-Paneri P, Bonos E (2011) Microalgae: a novel ingredient in nutrition. Int $\mathrm{J}$ Food Sci Nutr 62(8):794-799

Chronakis IS, Madsen M (2011) Algal proteins. In Handbook of food proteins: Woodhead Publishing. 353-394

Chye JTT, Jun LY, Yon LS, Pan S, Danquah MK (2018) Biofuel production from algal biomass.Bioenergy and Biofuels621

Cottin SC, Sanders TA, Hall WL (2011) The differential effects of EPA and DHA on cardiovascular risk factors. Proc. Nutr. Soc. P. NUTR. SOC. 70 (2), 215-231

Daneshvar E, Wicker RJ, Show PL, Bhatnagar A (2022) Biologically-mediated carbon capture and utilization by microalgae towards sustainable $\mathrm{CO} 2$ biofixation and biomass valorization-A review. Chem Eng J 427:130884

Daroch M, Geng S, Wang G (2013) Recent advances in liquid biofuel production from algal feedstocks. Appl Energy 102:1371-1381

Dasgupta CN, Gilbert JJ, Lindblad P, Heidorn T, Borgvang SA, Skjanes K, Das D (2010) Recent trends on the development of photobiological processes and photobioreactors for the improvement of hydrogen production. Int J Hydrog Energy 35(19):10218-10238

Dawczynski C, Schubert R, Jahreis G (2007) Amino acids, fatty acids, and dietary fibre in edible seaweed products. Food Chem 103(3):891-899

Dębowski M, Zieliński M, Kisielewska M, Hajduk A (2016) Effect of constant magnetic field on anaerobic digestion of algal biomass. Environ Technol 37(13):1656-1663 
Del Mondo A, Smerilli A, Sané E, Sansone C, Brunet C (2020) Challenging microalgal vitamins for human health. Microb Cell Factories 19(1):1-23

de Raposo J, Dde Morais MFDJ, Bernardo, de Morais AR.M.MS.C., 20134. Bioactivity and applications of sulphated polysaccharides from marine microalgae. Mar. DrugsPolysaccharides: Bioactivity and biotechnology 11 (1)

Dineshbabu G, Uma VS, Mathimani T, Deviram G, Ananth DA, Prabaharan D, Uma L (2017) On-site concurrent carbon dioxide sequestration from flue gas and calcite formation in ossein effluent by a marine cyanobacterium Phormidium valderianum $B D U 20041$ Energy Convers Manag 141:315-324

Dong T, Knoshaug EP, Davis R, Laurens LM, Van Wychen S, Pienkos PT, Nagle N (2016) Combined algal processing: A novel integrated biorefinery process to produce algal biofuels and bioproducts. Algal Res 19:316-323

Edelmann M, Aalto S, Chamlagain B, Kariluoto S, Piironen V (2019) Riboflavin, niacin, folate and vitamin B12 in commercial microalgae powders. J Food Compos Anal $82: 103226$

El-Dalatony MM, Salama ES, Kurade MB, Kim KY, Govindwar SP, Kim JR, Jeon BH (2019) Whole conversion of microalgal biomass into biofuels through successive highthroughput fermentation. Chem Eng J 360:797-805

Eroglu E, Melis A (2011) Photobiological hydrogen production: recent advances and state of the art. Bioresour Technol 102(18):8403-8413

Fabris M, Abbriano RM, Pernice M, Sutherland DL, Commault AS, Hall CC, Ralph PJ (2020) Emerging technologies in algal biotechnology: toward the establishment of a sustainable, algae-based bioeconomy.Front. Plant Sci.11

Faruque MO, Razzak SA, Hossain MM (2020) Application of Heterogeneous Catalysts for Biodiesel Production from Microalgal Oil-A. Review Catalysts 10(9):1025

Fernando IS, Kim M, Son KT, Jeong Y, Jeon YJ (2016) Antioxidant activity of marine algal polyphenolic compounds: a mechanistic approach. J Med Food 19(7):615-628

Ferraces-Casais P, Lage-Yusty MA, De Quirós ARB, LópezHernández J (2012) Evaluation of bioactive compounds in fresh edible seaweeds. Food Anal Methods 5(4):828-834

Figueroa-Torres GM, Mahmood WMAW, Pittman JK, Theodoropoulos C (2020) Microalgal biomass as a biorefinery platform for biobutanol and biodiesel production. Biochem Eng J 153:107396

Fleita D, El-Sayed M, Rifaat D (2015) Evaluation of the antioxidant activity of enzymatically-hydrolysed sulfated polysaccharides extracted from red algae; Pterocladia capillacea LWT- FOOD SCI TECHNOL 63(2):1236-1244

Francavilla M, Colaianna M, Zotti M, Morgese G, Trotta GM, Tucci P, Trabace P (2012) Extraction, characterisation and in vivo neuromodulatory activity of phytosterols from microalga Dunaliella tertiolecta Curr Med Chem 19(18):3058-3067

Gaignard C, Laroche C, Pierre G, Dubessay P, Delattre C, Gardarin C, Michaud P (2019) Screening of marine microalgae: Investigation of new exopolysaccharide producers. Algal Res 44:101711
Galasso C, Gentile A, Orefice I, Ianora A, Bruno A, Noonan DM, Brunet C (2019) Microalgal derivatives as potential nutraceutical and food supplements for human health: A focus on cancer prevention and interception. Nutrients 11(6): 1226

Gastineau R, Turcotte F, Pouvreau JB, Morançais M, Fleurence J, Windarto E, Mouget JL (2014) Marennine, promising blue pigments from a widespread Haslea diatom species complex Mar Drugs 12(6):3161-3189

Geada P, Moreira C, Silva M, Nunes R, Madureira L, Rocha CM, Teixeira JA (2021) Algal proteins: Production strategies and nutritional and functional properties.Bioresour. Technol.125125

Gendy TS, El-Temtamy SA (2013) Commercialisation potential aspects of microalgae for biofuel production: an overview. Egypt J Pet 22(1):43-51

Gharajeh NH, Valizadeh M, Dorani E, Hejazi MA (2020) Biochemical profiling of three indigenous Dunaliella isolates with main focus on fatty acid composition towards potential biotechnological application.Biotechnol. Rep.26, e00479

Global Algae Market Analysis Report, 2019-2025. Promising Pre-Commercial Success of Biofuel Production from Algae Signals Robust Opportunities.Business wire, Dublin, Ireland

González-Delgado ÁD, Kafarov V (2011) Microalgae based biorefinery: Issues to consider. CT F-Cienc. Tecn Fut 4(4):5-22

González-López CV, García-Cuadra F, Jawiarczyk N, Fernández-Sevilla JM, Acién-Fernández FG (2020) Valorization of Microalgae and Energy Resources. In Sustainable Mobility. IntechOpen

Guedes AC, Amaro HM, Malcata FX (2011) Microalgae as sources of carotenoids. Mar Drugs 9(4):625-644

Gupta A, Barrow CJ, Puri M (2012) Omega-3 biotechnology: Thraustochytrids as a novel source of omega-3 oils. Biotechnol Adv 30(6):1733-1745

Gupta VK, Potumarthi R, O’Donovan A, Kubicek CP, Sharma GD, Tuohy MG (2014) Bioenergy research: an overview on technological developments and bioresources. Bioenergy research: advances and applications. 23-47

Hamilton ML, Warwick J, Terry A, Allen MJ, Napier JA, Sayanova O (2015) Towards the industrial production of omega-3 long chain polyunsaturated fatty acids from a genetically modified diatom Phaeodactylum tricornutum.PloS One10 (12), e0144054

Hariz HB, Takriff MS, Yasin NHM, Ba-Abbad MM, Hakimi NINM (2019) Potential of the microalgae-based integrated wastewater treatment and $\mathrm{CO} 2$ fixation system to treat Palm Oil Mill Effluent (POME) by indigenous microalgae; Scenedesmus sp. and Chlorella sp J Water Process Eng 32:100907

Harwood JL (2019) Algae: critical sources of very long-chain polyunsaturated fatty acids. Biomolecules 9(11):708

Hashemian M, Ahmadzadeh H, Hosseini M, Lyon S, Pourianfar HR (2019) Production of microalgae-derived high-protein biomass to enhance food for animal feedstock and human consumption. Advanced bioprocessing for alternative fuels, biobased chemicals, and bioproducts.s. Woodhead Publishing, 393-405, pp 393-405 
Hena S, Fatihah N, Tabassum S, Ismail N (2015) Three stage cultivation process of facultative strain of Chlorella sorokiniana for treating dairy farm effluent and lipid enhancement. Water Res Water research 80:346-356

Hernández D, Solana M, Riaño B, García-González MC, Bertucco A (2014) Biofuels from microalgae: lipid extraction and methane production from the residual biomass in a biorefinery approach. Bioresour Technol 170:370-378

Hossain SZ (2019) Biochemical conversion of microalgae biomass into biofuel. Chem Eng Technol 42(12):2594-2607

Jerez-Martel I, García-Poza S, Rodríguez-Martel G, Rico M, Afonso-Olivares C, Gómez-Pinchetti JL (2017) Phenolic profile and antioxidant activity of crude extracts from microalgae and cyanobacteria strains. J. Food Quality 2017

Jeske M, Trentini AM, Bontempo M (2011) Clorela, o alimento completo, Compêndio de Fitoterapia.Manual da Medicina Integral. pp.1-2

Jimenez-Lopez C, Pereira AG, Lourenço-Lopes C, Garcia-Oliveira P, Cassani L, Fraga-Corral M, Simal-Gandara J (2021) Main bioactive phenolic compounds in marine algae and their mechanisms of action supporting potential health benefits. Food Chem 341:128262

Ji SQ, Wang B, Lu M, Li FL (2016) Defluviitalea phaphyphila sp. nov., a novel thermophilic bacterium that degrades brown algae. Appl Environ Microbiol 82(3):868

Jönsson M, Allahgholi L, Sardari RR, Hreggviðsson GO, Karlsson N (2020) Extraction and modification of macroalgal polysaccharides for current and next-generation applications. Molecules 25(4):930

Kainarbayeva ZN, Kartay AM, Sarieva RB, Donenov BK, Umerzakova MB (2019) Microalgal Biomass as a Raw Material for Producing Surfactants. Russ J Appl Chem 92(7):964-971

Kapoore RV, Butler TO, Pandhal J, Vaidyanathan S (2018) Microwave-assisted extraction for microalgae: from biofuels to biorefinery. Biol 7(1):18

Karpagam R, Jawaharraj K, Gnanam R (2021) Review on integrated biofuel production from microalgal biomass through the outset of transesterification route: a cascade approach for sustainable bioenergy. Sci. Total Environ., 766, p. 144236

Khan MI, Shin JH, Kim JD (2018) The promising future of microalgae: current status, challenges, and optimisation of a sustainable and renewable industry for biofuels, feed, and other products. Microb Cell Factories 17(1):1-21

Khosravitabar F (2019) Microalgal biohydrogen photoproduction: scaling up challenges and the ways forward.J. Appl. Phycol.1-13

Khosravitabar F, Hippler M (2019) A new approach for improving microalgal biohydrogen photoproduction based on safe \& fast oxygen consumption. Int J Hydrog Energy 44(33):17835-17844

Kim D, Kim S, Han JI, Yang JW, Chang YK, Ryu BG (2019) Carbon balance of major volatile fatty acids (VFAs) in recycling algal residue via a VFA-platform for reproduction of algal biomass. Environ Manag Today 237:228-234

Kinnunen HV, Koskinen PEP, Rintala J (2014) Mesophilic and thermophilic anaerobic laboratory-scale digestion of Nannochloropsis microalga residues. Bioresour Technol 155:314-322
Kleinert C, Griehl C (2021) Identification of suitable Botryococcus braunii strains for non-destructive in situ hydrocarbon extraction. J Appl Phycol Journal of Applied Phycology 33(2):785-798

Kosourov SN, He M, Allahverdiyeva Y, Seibert M (2018) Immobilisation of Microalgae as a Tool for Efficient Light Utilization in $\mathrm{H} 2$ Production and Other Biotechnology Applications. In Microalgal Hydrogen Production. 355-384

Koyande AK, Chew KW, Rambabu K, Tao Y, Chu DT, Show PL (2019a) Microalgae: A potential alternative to health supplementation for humans. Food Sci Hum Well 8(1):16-24

Koyande AK, Show PL, Guo R, Tang B, Ogino C, Chang JS (2019b) Bio-processing of algal bio-refinery: a review on current advances and future perspectives. Bioengineered 10(1):574-592

Kumar M, Khosla K, Thakur IS (2017) Optimisation of process parameters for the production of biodiesel from carbon dioxide sequestering bacterium. JEES 3:43-50

Kumar D, Singh B (2019) Algal biorefinery: An integrated approach for sustainable biodiesel production. Biomass Bioenergy 131:105398

Kumar AK, Sharma S, Patel A, Dixit G, Shah E (2019) Comprehensive evaluation of microalgal based dairy effluent treatment process for clean water generation and other value added products. Int $\mathbf{J}$ Phytoremediation 21(6):519-530

Kumar M, Sun Y, Rathour R, Pandey A, Thakur IS, Tsang DC (2020) Algae as potential feedstock for the production of biofuels and value-added products: Opportunities and challenges. Sci Total Environ 716:137116

Kumar AN, Yoon JJ, Kumar G, Kim SH (2020a) Biotechnological valorisation of algal biomass: an overview.Systems Microbiology and Biomanufacturing.1-11

Lai YS, McCaw A, Ontiveros-Valencia A, Shi Y, Parameswaran P, Rittmann BE (2016) Multiple synergistic benefits of selective fermentation of Scenedesmus biomass for fuel recovery via wet-biomass extraction. Algal Res $17: 253-260$

Lane K, Derbyshire E, Li W, Brennan C (2014) Bioavailability and potential uses of vegetarian sources of omega-3 fatty acids: a review of the literature. Crit Rev Food Sci Nutr 54(5):572-579

Laurens LM, Markham J, Templeton DW, Christensen ED, Van Wychen S, Vadelius EW, Pienkos PT (2017) Development of algae biorefinery concepts for biofuels and bioproducts; a perspective on process-compatible products and their impact on cost-reduction. Energy Environ Sci 10(8):1716-1738

LEFLAIVE JP, Ten-Hage LOÏC (2007) Algal and cyanobacterial secondary metabolites in freshwaters: a comparison of allelopathic compounds and toxins. Freshw Biol 52(2):199-214

Lima S, Webb CL, Deery E, Robinson C, Zedler JA (2018) Human intrinsic factor expression for bioavailable vitamin B12 enrichment in microalgae. Biol 7(1):19

Liu J, Hu Q (2013) Chlorella: industrial production of cell mass and chemicals. Handbook of microalgal culture: applied phycology and biotechnology. 329-338 
Liu D, Ma Q, Valiela I et al (2021) Role of C4 carbon fixation in Ulva prolifera, the macroalga responsible for the world's largest green tides. Commun Biol 3:494

Llamas M, Greses S, Tomás-Pejó E, González-Fernández C (2021) Tuning Microbial Community in Non-Conventional Two-Stage Anaerobic Bioprocess for Microalgae Biomass Valorization into Targeted Bioproducts.Bioresource Technology, 125387

Makatsoris C, Alissandratos A (2019) "Modular continuous photobiochemical reactor", WO/2019/016575

Malik P, Sangwan A (2012) Nanotechnology: A tool for improving efficiency of bio-energy.J. Eng. Appl. Sci.1,37-49

Manach C, Scalbert A, Morand C, Rémésy C, Jiménez L (2004) Polyphenols: food sources and bioavailability. Am J Clin Nutr 79(5):727-747

Mandik YI, Cheirsilp B, Srinuanpan S, Maneechote W, Boonsawang P, Prasertsan P, Sirisansaneeyakul S (2020) Zerowaste biorefinery of oleaginous microalgae as promising sources of biofuels and biochemicals through direct transesterification and acid hydrolysis. Process Biochem 95:214-222

Marella ER, Holkenbrink C, Siewers V, Borodina I (2018) Engineering microbial fatty acid metabolism for biofuels and biochemicals. Curr Opin Biotech 50:39-46

Margulis L (1981) Symbiosis in cell evolution: Life and its environment on the early earth

Marin-Batista JD, Villamil JA, Rodriguez JJ, Mohedano AF, De la Rubia MA (2019) Valorisation of microalgal biomass by hydrothermal carbonisation and anaerobic digestion. Bioresour Technol 274:395-402

Markou G, Ilkiv B, Brulé M, Antonopoulos D, Chakalis L, Arapoglou D, Chatzipavlidis I (2020) Methane production through anaerobic digestion of residual microalgal biomass after the extraction of valuable compounds.Biomass Convers. Biorefin. 1-8

Mata TM, Martins AA, Caetano NS (2010) Microalgae for biodiesel production and other applications: a review. Renew Sustain Energy Rev 14(1):217-232

Medipally SR, Yusoff FM, Banerjee S, Shariff M (2015) Microalgae as sustainable renewable energy feedstock for biofuel production. BioMed Res. Int. 2015

Meléndez-Martínez AJ, Mapelli-Brahm P, Stinco CM (2018) The colourless carotenoids phytoene and phytofluene: From dietary sources to their usefulness for the functional foods and nutricosmetics industries. J Food Compos Anal 67:91-103

Michalak I, Chojnacka K (2015) Algae as production systems of bioactive compounds. Eng Life Sci 15(2):160-176

Milledge JJ (2011) Commercial application of microalgae other than as biofuels: a brief review. Rev Environ Sci Biotechnol Reviews in Environmental Science and Bio/ Technology 10(1):31-41

Milledge JJ, Nielsen BV, Maneein S, Harvey PJ (2019) A brief review of anaerobic digestion of algae for bioenergy. Energies 12(6):1166

Mišurcová L, Buňka F, Ambrožová JV, Machů L, Samek D, Kráčmar S (2014) Amino acid composition of algal products and its contribution to RDI. Food chem 51:120-125

Mohan SV, Dahiya S, Amulya K, Katakojwala R, Vanitha TK (2019) Can circular bioeconomy be fueled by waste
biorefineries-A closer look. Bioresour Technol Reports 7:100277

Mohan SV, Hemalatha M, Chakraborty D, Chatterjee S, Ranadheer P, Kona R (2019) Algal biorefinery models with self-sustainable closed loop approach: Trends and prospective for blue-bioeconomy. Bioresour Technol 295: 122128

Morales-Contreras BE, Flórez-Fernández N, Torres MD, Domínguez H, Rodríguez-Jasso RM, Ruiz HA (2022) Hydrothermal systems to obtain high value-added compounds from macroalgae for bioeconomy and biorefineries. Bioresour Technol 343:126017

Moustafa Y, Batran A (2014) Lipid chemistry of green macroalgae Ulva sp. a potential resource for biotechnological applications in the Southern Mediterranean Sea Coast, Alexandria shore. Egypt Egypt J Aquat Biol Fish 18(4):9-20

Necas J, Bartosikova L (2013) Carrageenan: a review.Vet. Med. (Praha).58(4)

Nematian T, Shakeri A, Salehi Z, Saboury AA (2020) Lipase immobilised on functionalised superparamagnetic fewlayer graphene oxide as an efficient nanobiocatalyst for biodiesel production from Chlorella vulgaris bio-oil. Biotechnol Biofuels 13(1):1-15

Nirmala N (2020) Phylogenetic analysis for identification of lipid enriched microalgae and optimization of extraction conditions for biodiesel production using response surface methodology tool. Biocatal Agric Biotechnol 25:101603

Nyberg M, Heidorn T, Lindblad P (2015) Hydrogen production by the engineered cyanobacterial strain Nostoc PCC 7120 $\Delta$ hupW examined in a flat panel photobioreactor system. J Biotechnol 215:35-43

Oliver L, Dietrich T, Marañón I, Villarán MC, Barrio RJ (2020) Producing Omega-3 Polyunsaturated Fatty Acids: A Review of Sustainable Sources and Future Trends for the EPA and DHA Market. Resour 9(12): 148

Omega 3 Market Size, Share \& Trends Analysis Report By Type (EPA, DHA, ALA), By Source (Marine Source, Plant Source), By Application, By Region, And Segment Forecasts, 2020-2027, Grand View Research p.100. https:// www.grandviewresearch.com/industry-analysis/omega-3market

Park JY, Park MS, Lee YC, Yang JW (2015) Advances in direct transesterification of algal oils from wet biomass. Bioresour Technol 184:267-275

Patil PD, Gude VG, Mannarswamy A, Cooke P, Nirmalakhandan N, Lammers P, Deng S (2012) Comparison of direct transesterification of algal biomass under supercritical methanol and microwave irradiation conditions. Fuel 97:822-831

Patil NP, Le V, Sligar AD, Mei L, Chavarria D, Yang EY, Baker AB (2018) Algal polysaccharides as therapeutic agents for atherosclerosis Front cardiovasc med 5:153

Pereira AM, Lisboa CR, Costa JAV (2018) High protein ingredients of microalgal origin: Obtainment and functional properties. Innov Food Sci Emerg Technol 47:187-194

Pfleger BF, Gossing M, Nielsen J (2015) Metabolic engineering strategies for microbial synthesis of oleochemicals. Metab Eng 29:1-11 
Pierre G, Delattre C, Dubessay P, Jubeau S, Vialleix C, Cadoret JP, Michaud P (2019) What is in store for EPS microalgae in the next decade? Molecules 24(23):4296

Pimentel FB, Alves RC, Rodrigues F, Oliveira PP (2018) Macroalgae-derived ingredients for cosmetic industryAn update. Cosmetics 5(1):2

Piwowar A, Harasym J (2020) The Importance and Prospects of the Use of Algae in Agribusiness. Sustain 12(14):5669

Pleissner D, Lau KY, Zhang C, Lin CSK (2015) Plasticiser and Surfactant Formation from Food-Waste-and. Algal Biomass-Derived Lipids ChemSusChem 8(10):1686-1691

Prajapati SK, Bhattacharya A, Kumar P, Malik A, Vijay VK (2016) A method for simultaneous bioflocculation and pretreatment of algal biomass targeting improved methane production. Green Chem 18(19):5230-5238

Radmann EM, de Morais EG, de Oliveira CF, Zanfonato K, Costa JAV (2015) Microalgae cultivation for biosurfactant production. Afr J Microbiol Res 9(47):2283-2289

Rajendran I (2020) Marine Algal Polysaccharides and Their Applications. Encyclopedia of Marine Biotechnology 2:1195-1208

Rashid N, Rehman MSU, Memon S, Rahman ZU, Lee K, Han JI (2013) Current status, barriers and developments in biohydrogen production by microalgae. Renew Sustain Energy Rev 22:571-579

Ras M, Lardon L, Bruno S, Bernet N, Steyer JP (2011) Experimental study on a coupled process of production and anaerobic digestion of Chlorella vulgaris Bioresour Technol 102(1):200-206

Razzak SA (2018) Biomass and Lipid Productivity of Neochloris oleoabundans for $\mathrm{CO} 2$ Biofixation and Biodiesel Application. Chem Eng Technol Chemical Engineering \& Technology 41(11):2177-2185

Remize M, Brunel Y, Silva JL, Berthon JY, Filaire E (2021) Microalgae n-3 PUFAs Production and Use in Food and Feed Industries. Mar Drugs 19(2):113

Ruiz J, Olivieri G, De Vree J, Bosma R, Willems P, Reith JH, Barbosa MJ (2016) Towards industrial products from microalgae. Energy Environ Sci 9(10):3036-3043

Sajjadi B, Chen WY, Raman AAA, Ibrahim S (2018) Microalgae lipid and biomass for biofuel production: A comprehensive review on lipid enhancement strategies and their effects on fatty acid composition. Renew Sustain Energy Rev Renewable and Sustainable Energy Reviews 97:200-232

Santhosh S, Dhandapani R, Hemalatha N (2016) Bioactive compounds from microalgae and its different applications - A review. Adv Appl Sci Res 7:153-158

Santiago-Morales IS, Trujillo-Valle L, Márquez-Rocha FJ, Hernández JFL (2018) Tocopherols, phycocyanin and superoxide dismutase from microalgae: as potential food antioxidants. Appl. Food Biotechnol. 5(1), 19-27

Santos-Ballardo DU, Font-Segura X, Ferrer AS, Barrena R, Rossi S, Valdez-Ortiz A (2015) Valorisation of biodiesel production wastes: Anaerobic digestion of residual Tetraselmis suecica biomass and co-digestion with glycerol. Waste Manag Res 33(3):250-257

Sathasivam R, Radhakrishnan R, Hashem A, Abd-Allah EF (2019) Microalgae metabolites: A rich source for food and medicine. Saudi J Biol Sci 26(4):709-722
Schlagermann P, Göttlicher G, Dillschneider R, Rosello-Sastre R, Posten C (2012) Composition of algal oil and its potential as biofuel. J. Combust. Journal of combustion, 2012

Shokravi Z, Shokravi H, Chyuan OH, Lau WJ, Koloor SSR, Petrů M, Ismail AF (2020) Improving 'Lipid Productivity'in Microalgae by Bilateral Enhancement of Biomass and Lipid Contents: A Review. Sustain Sustainability 12(21):9083

Show PL, Tang MS, Nagarajan D, Ling TC, Ooi CW, Chang JS (2017) A holistic approach to managing microalgae for biofuel applications. Int J Mol Sci 18(1):215

Silva CEDF, Bertucco A (2019) Bioethanol from microalgal biomass: a promising approach in biorefinery.Braz. Arch. Biol. Technol.62

Singh J, Dhar DW (2019) Overview of carbon capture technology: microalgal biorefinery concept and state-of-theart. Front Mar Sci 6:29

Singh J, Thakur IS (2015) Evaluation of cyanobacterial endolith Leptolyngbya sp. ISTCY101, for integrated wastewater treatment and biodiesel production: a toxicological perspective. Algal Res 11:294-303

Singh J, Tripathi R, Thakur IS (2014) Characterisation of endolithic cyanobacterial strain, Leptolyngbya sp. ISTCY101, for prospective recycling of CO2 and biodiesel production. Bioresour Technol 166:345-352

Singh DP, Khattar JS, Rajput A, Chaudhary R, Singh R (2019) High production of carotenoids by the green microalga Asterarcys quadricellulare PUMCC 5.1. 1 under optimised culture conditions.PloS one14 (9), e0221930

Singh R, Bux F, Sharma YC (2020) Optimisation of biodiesel synthesis from microalgal (Spirulina platensis) oil by using a novel heterogeneous catalyst, $\beta$-strontium silicate $(\beta$ Sr2SiO4). Fuel 280:118312

Sivaramakrishnan R, Incharoensakdi A (2018) Utilization of microalgae feedstock for concomitant production of bioethanol and biodiesel. Fuel 217:458-466

Smerilli A, Orefice I, Corato F, Gavalás Olea A, Ruban AV, Brunet C (2017) Photoprotective and antioxidant responses to light spectrum and intensity variations in the coastal diatom $S$ keletonema marinoi Environ Microbiol 19(2):611-627

Smith AJ, Graves B, Child R, Rice PJ, Ma Z, Lowman DW, Williams DL (2018) Immunoregulatory activity of the natural product laminarin varies widely as a result of its physical properties. J Immunol 200(2):788-799

Solomons NW (2012) Vitamin A. Present knowledge in nutrition. 149-184

Sousa I, Gouveia L, Batista AP, Raymundo A, Bandarra NM (2008) Microalgae in novel food products. Food chemistry research developments.75-112

Srivastava G, Kumar V, Tiwari R, Patil R, Kalamdhad A, Goud V 2020 Anaerobic co-digestion of defatted microalgae residue and rice straw as an emerging trend for waste utilization and sustainable biorefinery development.Biomass Convers. Biorefin.1-10

Stern RF, Horak A, Andrew RL, Coffroth MA, Andersen RA, Küpper FC, Keeling PJ (2010) Environmental barcoding reveals massive dinoflagellate diversity in marine environments.PloS one5 (11), e13991 
Stiles WA, Styles D, Chapman SP, Esteves S, Bywater A, Melville L, Llewellyn CA (2018) Using microalgae in the circular economy to valorise anaerobic digestate: challenges and opportunities. Bioresour Technol 267:732-742

Subhash GV, Mohan SV (2014) Deoiled algal cake as feedstock for dark fermentative biohydrogen production: an integrated biorefinery approach. Int $\mathrm{J}$ Hydrog Energy 39(18):9573-9579

Subhash GV, Rajvanshi M, Kumar GRK, Sagaram US, Prasad V, Govindachary S, Dasgupta S (2022) Challenges in microalgal biofuel production: A perspective on techno economic feasibility under biorefinery stratagem. Bioresour Technol 343:126155

Suganya T, Varman M, Masjuki HH, Renganathan S (2016) Macroalgae and microalgae as a potential source for commercial applications along with biofuels production: a biorefinery approach. Renew Sustain Energy Rev 55:909-941

Takahashi K, Hosokawa M, Kasajima H, Hatanaka K, Kudo K, Shimoyama N, Miyashita K (2015) Anticancer effects of fucoxanthin and fucoxanthinol on colorectal cancer cell lines and colorectal cancer tissues. Oncol Lett 10(3):1463-1467

Tan IS, Lam MK, Foo HCY, Lim S, Lee KT (2020) Advances of macroalgae biomass for the third generation of bioethanol production. Chin J Chem Eng 28(2):502-517

Tan JS, Lee SY, Chew KW, Lam MK, Lim JW, Ho SH, Show PL (2020) A review on microalgae cultivation and harvesting, and their biomass extraction processing using ionic liquids. Bioengineered 11(1):116-129

Tao F, Cheng J, Qi Q, Zhang M, Zhang H, Sui F (2018) Digital twin-driven product design, manufacturing and service with big data. Nt J Adv Manuf Tech 94(9):3563-3576

Tedesco S, Stokes J (2017) Valorisation to biogas of macroalgal waste streams: a circular approach to bioproducts and bioenergy in Ireland. Chem Zvesti 71(4):721-728

Thangaraj B, Solomon PR, Muniyandi B, Ranganathan S, Lin L (2019) Catalysis in biodiesel production-a review. Clean Energy 3(1):2-23

Thawechai T, Cheirsilp B, Louhasakul Y, Boonsawang P, Prasertsan P (2016) Mitigation of carbon dioxide by oleaginous microalgae for lipids and pigments production: Effect of light illumination and carbon dioxide feeding strategies. Bioresour Technol 219:139-149

The next big superfood could be green and slimy [Internet]. Baehr: c2011 [cited 07 August 2017]. Available from: http://www.businessinsider.com/algae-is-the-super-foodof-the-future-2014-6

Uhlemann THJ, Lehmann C, Steinhilper R (2017) The digital twin: Realising the cyber-physical production system for industry 4.0. Procedia Cirp 61:335-340

Ullmann J, Grimm D (2021) Algae and their potential for a future bioeconomy, landless food production, and the socio-economic impact of an algae industry.Org. Agric.1-7

Uma VS, Gnanasekaran Dineshbabu (2020). Biobased lipid and fats from microalgae In Recent Advances in Bioenergy Research 2nd Edition: Elsevier. 273-298

Uma VS, Gnanasekaran D, Lakshmanan U, Dharmar P (2020) Survey and isolation of marine cyanobacteria from eastern coast of India as a biodiesel feedstock. Biocatal Agric Biotechnol 24:101541

Vavilala SL, D'Souza JS (2015) Algal polysaccharides and their biological applications. Marine Algae Extracts. WileyBlackwell, Weinheim, pp 411-415

Veerabadhran M, Gnanasekaran D, Wei J, Yang F (2021) Anaerobic digestion of microalgal biomass for bioenergy production, removal of nutrients and microcystin: Current status. J. Appl. Microbiol

Veillette M, Giroir-Fendler A, Faucheux N, Heitz M (2017) Esterification of free fatty acids with methanol to biodiesel using heterogeneous catalysts: from model acid oil to microalgae lipids. Chem Eng J 308:101-109

Vermuë MH, Eppink MHM, Wijffels RH, Van Den Berg C (2018) Multi-product microalgae biorefineries: from concept towards reality. Trends Biotechnol 6(2):216-227

Wang Y, Jiang X, Hu C, Sun T, Zeng Z, Cai X, Hu Z (2017) Optogenetic regulation of artificial microRNA improves $\mathrm{H}$ 2 production in green alga Chlamydomonas reinhardtii Biotechnol Biofuels 10(1):1-9

Wang Y, Yu J, Wang P, Deng S, Chang J, Ran Z (2018) Response of energy microalgae Chlamydomonas reinhardtii to nitrogen and phosphorus stress. Environ Sci Pollut Res 25(6):5762-5770

Wang L, Chen L, Yang S, Tan X (2020) Photosynthetic conversion of carbon dioxide to oleochemicals by cyanobacteria: Recent advances and future perspectives.Front. Microbiol.11

Ward AJ, Lewis DM, Green FB (2014) Anaerobic digestion of algae biomass: a review. Algal Res 5:204-214

Watanabe F, Yabuta Y, Tanioka Y, Bito T (2013) Biologically active vitamin B12 compounds in foods for preventing deficiency among vegetarians and elderly subjects J. Agric. Food Chem 61(28):6769-6775

Wells ML, Potin P, Craigie JS, Raven JA, Merchant SS, Helliwell KE, Brawley SH (2017) Algae as nutritional and functional food sources: revisiting our understanding. J Appl Phycol 29(2):949-982

Xia A, Cheng J, Lin R, Lu H, Zhou J, Cen K (2013) Comparison in dark hydrogen fermentation followed by photo hydrogen fermentation and methanogenesis between protein and carbohydrate compositions in Nannochloropsis oceanica biomass. Bioresour Technol 138:204-213

Xia A, Cheng J, Song W, Su H, Ding L, Lin R, Cen K (2015) Fermentative hydrogen production using algal biomass as feedstock. Renew Sustain Energy Rev 51:209-230

Yadav G, Dash SK, Sen R (2019) A biorefinery for valorization of industrial waste-water and flue gas by microalgae for waste mitigation, carbon-dioxide sequestration and algal biomass production. Sci Total Environ 688:129-135

Yen HW, Hu IC, Chen CY, Ho SH, Lee DJ, Chang JS (2013) Microalgae-based biorefinery-from biofuels to natural products. Bioresour Technol 135:166-174

Yin FW, Guo DS, Ren LJ, Ji XJ, Huang H (2018) Development of a method for the valorisation of fermentation wastewater and algal-residue extract in docosahexaenoic acid production by Schizochytrium sp Bioresour Technol 266:482-487

Yuan Y, Zhang J, Fan J, Clark J, Shen P, Li Y, Zhang C (2018) Microwave assisted extraction of phenolic compounds from four economic brown macroalgae species and 
evaluation of their antioxidant activities and inhibitory effects on $\alpha$-amylase, $\alpha$-glucosidase, pancreatic lipase and tyrosinase Food Res Int 113:288-297

Yu AQ, Pratomo Juwono NK, Leong SSJ, Chang MW (2014) Production of fatty acid-derived valuable chemicals in synthetic microbes. Front Bioeng Biotechnol 2:78

Zabochnicka-Światek M (2010) Algae-feedstock of the future. Arch Combust 30(3):225-236

Zewdie DT, Ali AY (2020) Cultivation of microalgae for biofuel production: coupling with sugarcane-processing factories. Energy Sustain Soc 10(1):1-16
Zhang XL, Yan S, Tyagi RD, Surampalli RY (2013) Biodiesel production from heterotrophic microalgae through transesterification and nanotechnology application in the production. Renew Sustain Energy Rev 26:216-223

Publisher's Note Springer Nature remains neutral with regard to jurisdictional claims in published maps and institutional affiliations. 